\title{
Cell Therapy Replacement for Retinal and Optic Nerve Diseases: Cell Sources, Clinical Trials and Challenges
}

\author{
${ }^{*}$ Rosa M. Coco-Martin ${ }^{1,2}$ MD PhD rosa@ioba.med.uva.es \\ Salvador Pastor-Idoate 1,2,3 MD PhD pastoridoate.salvador@gmail.com \\ J. Carlos Pastor ${ }^{1,2,3,4}$ MD PhD pastor@ioba.med.uva.es \\ ${ }^{1}$ Instituto de Oftalmobiologia Aplicada (IOBA). Medical School, Universidad de \\ Valladolid, 47011 Valladolid, Spain. \\ 2 National Institute of Health Carlos III (ISCIII), (RETICS) Cooperative Health \\ Network for Research in Ophthalmology (Oftared), 28040 Madrid, Spain \\ ${ }^{3}$ Department of Ophthalmology. Hospital Clinico Universitario of Valladolid. \\ Valladolid. Spain. \\ ${ }^{4}$ Centro en Red de Medicina Regenerativa y Terapia Celular de Castilla y \\ León. Valladolid. Spain.
}

*Correspondence: rosa@ioba.med.uva.es; Tel.: +34-983423559

\begin{abstract}
The aim of this review was to provide an update on the potential of cell therapies to restore or replace damaged and/or lost cells in retinal degenerative and optic nerve diseases, describing the available cell sources and the challenges involved in such treatments when these techniques are applied in real clinical practice. Sources include human fetal retinal stem cells, allogenic cadaveric human cells, adult hippocampal neural stem cells, human CNS stem cells, ciliary pigmented epithelial cells, limbal stem cells, retinal progenitor cells (RPCs), human pluripotent stem cells (PSCs) (including both human embryonic stem cells (ESCs) and human induced pluripotent stem cells (iPSCs)) and mesenchymal stem cells (MSCs). Of these, RPCs, PSCs and MSCs have already entered early-stage clinical trials since they can all differentiate into RPE, photoreceptors or ganglion cells, and have demonstrated safety, while showing some indicators of efficacy. Stem/progenitor cell therapies for retinal diseases still have some drawbacks, such as the inhibition of proliferation and/or differentiation in vitro (with the exception of RPE) and the limited longterm survival and functioning of grafts in vivo. Some other issues remain to be solved concerning the clinical translation of cell-based therapy, including (1) the ability to enrich for specific retinal subtypes; (2) cell survival; (3) cell delivery, which may need to incorporate a scaffold to induce correct cell polarization, which increases the size of the retinotomy in surgery and, therefore, the chance of severe complications; (4) the need to induce retinal detachment to perform the subretinal placement of the transplanted cell; and (5) the evaluation of the risk of tumor formation caused by the undifferentiated stem cells and prolific progenitor cells. Despite these challenges, stem/progenitor cells represent the most promising strategy for retinal and optic nerve disease treatment in the near future, and therapeutics assisted by gene techniques, neuroprotective compounds and artificial devices can be applied to fulfil clinical needs.
\end{abstract}

Keywords: stem cells, retinal diseases, optic nerve diseases, cell replacement, cell sources 


\section{Introduction}

Retinal degenerative diseases (RDs) have been largely characterized and are considered leading causes of blindness worldwide. They include age-related macular degeneration (AMD) and inherited retinal dystrophies (IRDs) such as retinitis pigmentosa (RP) and Stargardt's disease [1,2]. There is also some retinal degeneration associated with ischemic disorders such as diabetic retinopathy (DR) and retinal vascular occlusion (RVO), which are also relevant to this review $[3,4]$. All these disorders share some common pathophysiology pathways that lead to the early loss or dysfunction of photoreceptors and/or neural apoptosis. As part of the central nervous system (CNS), the retina has very low regenerative capability, which results in untreatable blindness [1-4]. The available therapies for some RDs can protect retinal neurons, rescue or slow disease progression or relieve symptoms, but currently there are hardly any treatments to restore vision, because at present, lost cells cannot be replaced. Stem cell-based therapy is an exciting, rapidly advancing area of translational research that has already entered the clinic. Some of the advantages of the eye as a target organ for cell-based therapy-mainly for the retina-are the following. Its anatomy and physiology are very well known; surgical techniques to access the retina are well established and are reasonably safe (in fact, they are routine clinical procedures everywhere); the subretinal space is a relatively immune-privileged site; the number of cells needed to restore vision may be relatively small; retinal imaging in the living human eye is available with high resolution non-invasive techniques; one eye can be used as a control; and finally, electrodiagnostic and psychophysical testing to assess functional recovery are also available and well characterized [5].

Rescue strategies seeking a trophic effect from stem/progenitor cell treatment have been investigated, but their efficacy and efficiency are generally restricted by the low rate of proliferation and/or differentiation of cells in vitro and by poor cellular survival, migration, integration and function in vivo, excluding RPEbased therapy for RD. Nevertheless, cell therapy assisted by gene techniques, neuroprotective compounds and artificial devices can be used in these diseases to fulfil clinical needs.

Regarding cell therapy in optic nerve diseases (ONDs), the situation has progress little in the last five years, compared to a review carried out by our group [6]. On the one hand, this is due to the heterogenicity of the pathologies that researchers have tried to treated with cell therapy, which in many cases affect some other parts of the CNS too, and it is also due to the obvious difficulties of access in delivering any treatment to some sections of the optic nerve. It should not be forgotten that the optic nerve (ON) is "born" in the retinal ganglion cells (RGCs) and extends to the lateral geniculate nucleus [7]. The category of so-called optic neuropathies includes a broad spectrum of diseases with various causes, including ischemia, inflammation, toxicity, nutritional deficiencies, glaucoma, trauma, congenital problems and hereditary diseases, in most cases as part of wider neurodegenerative processes [8]. The ON is basically composed of RGC axons, and like other adult neurons of the CNS, they do not have the ability to regenerate after injury. Many factors limit the regeneration of $\mathrm{RGC}$ axons. Some are derived from the inhibitory environment 
created after RGCs suffer axonal damage. Furthermore, oligodendrocytes secrete inhibitory proteins and other molecules which impede axon regrowth, unlike myelinating Schwann cells that promote axon regeneration in the peripheral nervous system, but these cells are not present in the ON. Astrocytes also release inhibitory molecules and proliferate, creating glial scars acting as physical barriers to axonal regeneration $[9,10,11]$. Moreover, many genes which are necessary for cellular proliferation and axon growth, although active in embryonic cells, are deeply suppressed in mature ones $[9,10]$. Finally, axonal injury also interrupts the transport of neurotrophic factors, resulting in an increase in pro-apoptotic proteins in RGCs [12,13,14].

Reviews on the use of intravitreal cell therapy to confer neuroprotection through their paracrine properties have been published by our group $[6,15]$. Several phase I and II clinical trials (CTs) have demonstrated the safety of many types of stem cells, and this fact has prompted researchers to continue to progress in the exploration of the efficacy of this approach $[15,16]$. However, there are still many unknowns to be solved, such as the best source of cells, the best route of administration, the possible means of inducing the regeneration of lost cells and above all how to maintain the possible beneficial effects in the long term [16]. These unknowns have to be resolved before any of the treatments become a regular part of clinical therapies. In this review, we provide an update on the potential of cell therapies to restore or replace damaged and/or lost cells in RD and OND, reviewing the available data on published CTs and describing the available cell sources and the challenges involved in applying such treatments in real clinical practice.

\section{Search Strategy and Selection Criteria}

This review cited CTs performed on cell therapy published in the PubMed, Web of Science, Scopus and ClinicalTrials.gov electronic databases in the most recent years up to December 2020. Potentially relevant papers were obtained using the following search terms in combination as Medical Subject Headings and text words: human, stem cell, cell therapy, clinical trials, intraocular injection, intravitreal injection, subretinal injection, retina, retinal diseases, optic nerve and optic nerve diseases. Only English papers or those with an English abstract were pre-selected. The reference lists of the selected publications were also scanned to identify additional relevant papers and the MEDLINE option "Related Articles" was also used.

\section{Cell Sources}

The sources of stem cells for transplantation include human fetal retinal stem cells, allogenic cadaveric human cells, adult hippocampal neural stem cells, human CNS stem cells, ciliary pigmented epithelial cells, limbal stem cells, retinal progenitor cells (RPCs), human pluripotent stem cells (hPSCs) (including both human embryonic stem cells (ESCs) and human induced pluripotent stem cells (iPSCs)) and mesenchymal stem cells (MSCs) [17,18]. Finally, cells extracted from the adult human RPE, obtained from eye banks and activated in vitro into a stem cell state (RPESCs), are a potential source of such cells [19]. Of these, RPCs, PSCs and MSCs have demonstrated their ability to assume some of the functions of native tissue and have all been used in an increasing 
number of CTs, since they all can differentiate into RPE, photoreceptors or ganglion cells [20].

RPCs are obtained from the fetal and postnatal retina. Their main advantages are their simple accessibility, safety and effectiveness, the fact that they are widely studied, avoid ethical issues and have low risk of immune rejection and tumorigenesis. Their disadvantages are the shortage of sufficient donor cells due to their limited proliferative capacity and their restricted ability to differentiate into specific types of cells [21].

MSCs may originate from amniotic fluid or the umbilical cord, although they are mainly obtained from two developmentally mature organs: bone marrow mesenchymal stem cells (BMMSCs) and adipose mesenchymal stem cells (ADMSCs). The latter are much more abundant and easier to harvest from donors, with less invasive procedures. Moreover, they expand faster and demonstrate a higher immunomodulatory capacity than BMMSCs. MSCs have been shown to have anti-inflammatory, immunosuppressive, angiogenic and anti-apoptotic or neuroprotective effects [22,23]. Furthermore, they are multipotent; thus, they have some ability to differentiate into damaged cells, although this is somewhat limited. They have a low rate of cell migration and differentiation, though have been reported to differentiate into photoreceptors and RPE cells. Nevertheless, it remains unclear if the newly observed cells may represent the fusion of MSCs with pre-existing photoreceptors [24,25].

Human ESCs come from developing embryos. Their main advantage is their ability to differentiate into photoreceptors under certain circumstances, creating an unlimited source of cells for RD treatment, whereas their main disadvantages are their limited proliferation and multi-differentiation into various cell types, thus presenting difficulties in obtaining the specific targeted cell type; their potential for tumor formation; the requirement of lifelong immunosuppressive therapies that increase risks and economic burdens; and finally, since ESCs are isolated from fetal tissues, they raise ethical concerns [26].

The need to provide large numbers of replacement cells has tipped the process toward the use of iPSCs. Various groups have developed protocols to induce and reprogram these cells since their introduction in 2006, and the next challenge will be to establish guidelines to determine their quality [27]. They are obtained from terminally differentiated tissues, which ameliorate the ethical issues of ESCs. They also have a low risk of immune rejection through autologous transplantation, with the disadvantage of a low differentiation efficiency despite their similar to ESCs, as well as biosafety concerns (e.g., the high risk of gene mutations) [21]. Furthermore, iPSCs have been critical in advancing our understanding of the underlying mechanisms (ontogenesis and pathology) of numerous retinal and optic nerve disorders such as AMD, RP and glaucoma. Cell models have been developed using iPSCs, and these are also important in the study of retinal disease, as well as in developing drug screening and gene therapy approaches. Finally, a new iPSC-based therapy for RD in humans was first reported by a Japanese group in 2017 [27]. 
On the other hand, stratified neural retina and RPE in a single complex could also be a potential tool in the development of a dual RPE/photoreceptor graft that could be used in individuals with end-stage RD. Recent studies have shown the formation of entire optic cups from ESCs in minimal media conditions [28]. Given the difficulty of the derivation of photoreceptors, especially for producing mature outer segments in 2D cultures [28], approaches using 3D retinal organoid cultures have been attempted. Considerable progress has been shown in the growth of self-organized 3D optic cups from human ESCs, which showed the formation of photoreceptors with reasonable inner segments and connecting cilia [28]. Other methods used for 3D organoid formation have been reported, mechanically picking them up from $2 \mathrm{D}$ cultures during differentiation and further optimizing them using a two-step culture system for human iPSCs [30]. Finally, there are also protocols for generating 3D optic vesicle-like structures from human iPSCs showing axon growth [31].

In the case of retinal vasculopathies, direct tissue replacement might be more challenging, as different cells are involved in their pathogenesis, such as the vascular endothelium, vascular pericytes, vascular smooth muscle, inner retinal neurons, photoreceptors and the retinal glia and microglia. Most researchers used MSCs and RPCs, which are considered to have some (although limited) ability to differentiate into the various cells damaged in the context of retinal vascular disease [32,33]. Thus, circulating vascular precursor cells CD34+ and endothelial progenitor cells (EPCs) have been used for tissue regeneration and angiogenesis following ischemia due to the fact that they may play a role in functional collateralization and secrete neurotrophic cytokines and proangiogenic factors [34,35]. CD34+ may differentiate into endothelial cells and because of this they are being explored in CTs as a potential therapy for various ischemic disorders, including ischemic cardiomyopathy, peripheral ischemia, cerebrovascular accidents, DR, retinal vein occlusion and ischemic optic neuropathy. Another potential cell source is a subpopulation of EPCs named outgrowth endothelial cells (OECs), which have significant proliferative potential but which need to be explored further as a therapy for ischemic retinopathy [39]. In addition, within the stromal vascular fraction of ADSCs there is a distinct population of cells that are thought to represent resident pericytes or their precursors. When these cells were administered intravitreally and intravenously into animal models of oxygen-induced retinopathy (OIR) and DR, the perivascular integration of these cells was observed with the rescue of retinal capillary damage [40]. One more approach would be to use subretinal transplantation of iPSCs (without c-Myc to minimize teratogenicity), because in rat eyes they were able to rescue the ischemic damaged retina through trophic paracrine effects. Moreover, researchers differentiated ESCs or iPSCs into endothelial precursor cells (particularly, endothelial colony unit-forming cells), and these showed some efficacy in treating an animal model of OIR [41]. Nevertheless, in a murine model of ischemia-reperfusion injury, vascular progenitor cells derived from ESCs and iPSCs from cord blood showed engraftment, homing and repair capabilities, whereas those derived from fibroblasts did not [42]. Lastly, extracellular stem cell-derived exosomes (MSCExos) may have a positive role in anatomical and functional restoration of the retina in retinal ischemia and DR by modulating angiogenesis and inflammation 
pathways, through immunomodulation or even through tissue regeneration $[43,44]$.

\section{Direct Cell Therapy Replacement for Retinal and Optic Nerve Diseases}

\section{RPE Replacement}

Human RPE cells were first isolated and characterized over 30 years ago, and since that time, cell replacement has been tested as a potential treatment for $\mathrm{RD}$. The second attempt at these cells' replacement occurred during the last decade, when RPE derivation from ESCs and iPSCs was established in many laboratories. The RPE cell layer does not require synaptic connections, unlike other cell types in the retina, but its ability to perform its essential functions depends on the RPE being a confluent monolayer with tight junctions and maintaining polarity for ion transport with a healthy Bruch's membrane $[45,46]$. Nevertheless, subretinal injection of healthy RPE cells allows them to maintain or improve the health of the outer nuclear, outer plexiform and photoreceptor inner/out segment layers [47]. An advantage of this is, as was mentioned before, that the subretinal space is a unique target for cell-based therapy because it is an immune-privileged environment in normal conditions.

Therefore, direct cell replacement is being explored as a potential therapy for macular atrophy, using stem cells injected into the submacular space, since RPE dysfunction and death in the macula is the main devastating feature of AMD and Stargardt's disease. This kind of cell therapy has also been launched for RP patients with monogenic mutations affecting RPE65, LRAT and MERTK, genes involved in visual signaling process dysfunction, specifically at the RPE level [48].

A cell product named CNTO2476, consisting of a suspension of human umbilical multipotent stem cells retrieved from donor umbilical cords (hUTSCs), has also been subretinally injected in patients with geographic atrophy due to AMD in a clinical trial (NCT01226628). The trial has been completed but its results have not been posted. Moreover, there are two open labeled CTs evaluating the safety and efficacy of autologous BMMNCs in the subretinal space of patients with RP (NCT01914913 and NCT02280135). These studies have not yet provided definitive data, but the preclinical results are promising in RPE diseases, in which the morphology of photoreceptors has seemed to improve. Two more CTs using BMMSC intravitreally are ongoing for RP patients (NCT01560715 and NCT01531348). Unfortunately, however, another CT has raised concerns about the safety of BMMSCs, as one out of three patients with advanced RP developed severe fibrous tissue proliferation at the injection site, in the vitreous cavity and in the retrolental space, which led to tractional retinal detachment. [49] One more ongoing CT in Saudi Arabia (NCT02016508) is investigating the safety and efficacy of the unilateral intravitreal injection of autologous BMMSC in subjects with geographic atrophy secondary to AMD [50].

Concerning hESCs, two cell products are being tested in CTs for macular diseases, one from Pfizer (NCT01691261) and the other from the Astellas Institute for Regenerative Medicine (formerly Ocata/Advanced Cell Technology). The latter is currently completing a phase I/Ila CT designed to test the 
tolerability of transplanted RPE cells derived from hESCs for the treatment of patients with Stargardt's disease (NCT01345006) and advanced dry AMD (NCT01344993) without a control group and using systemic immunosuppression. Indications of effectiveness have been shown, as 10 out of 18 patients improved their vision. There was no evidence of proliferation, rejection or serious systemic adverse events, but one patient had staphylococcus endophthalmitis, and cataract progression, localized RPE damage and intraocular inflammation were reported [51,52]. In addition, transplantation of hESM-derived RPE cells in the subretinal space with systemic immunosuppressive therapy for 13 weeks has been tested in 12 patients with Stargardt's disease (NCT01469832). In that trial, focal areas of subretinal hyperpigmentation were observed in all participants in a dose-dependent manner and no evidence of uncontrolled proliferation or inflammatory responses were found. Borderline improvements in best-corrected visual acuity (BCVA) in four participants either were unstained or showed a similar improvement in the untreated contralateral eye. Quality of life questionnaires and microperimetry demonstrated no evidence of a benefit at 12 months, and in one case, localized retinal thinning and reduced sensitivity in the area of hyperpigmentation suggested potential harm [53]. Lineage cell therapeutics has developed a similar study in patients with the advanced atrophic-form of AMD (still recruiting) that has the objective of evaluating the safety and tolerability of a cell product named OpRegen ${ }^{\circledR}$ (hESC-RPE cells) transplanted subretinally via the suprachoroidal approach through a microinjection using the Orbit Subretinal Delivery System (Orbit SDS) developed by Gyroscope Therapeutics (formerly Orbit Biomedical, Ltd.), which avoids the need to create a retinal hole and aims to provide precise and consistent dosing. The study will also assess the ability of transplanted OpRegen ${ }^{\circledR}$ cells to engraft, survive and moderate disease progression (NCT02286089) and results will be presented later this year. Furthermore, there are several recruiting phase I/II clinical trials using hEMS in AMD and/or Stargardt's disease in China (NCT02749734, NCT03046407 and NCT02755428), the United States (NCT01344993, NCT02463344, NCT02563782, NCT03167203, NCT01345006 and NCT02445612), France (NCT02941991 and NCT01469832) and Korea (NCT01625559 and NCT01674829) aiming to verify the overall safety and feasibility of hESC-RPE cell-based therapies, providing some promising early visual results, in which any major complications could be primarily attributed to the use of immunosuppressants during allogenic transplantation [48,54,55]. Finally, a phase I/II, open-label, prospective CT tried to determine the safety and tolerability of the subretinal transplantation of hESC-derived RPE cells (MA09$\mathrm{hRPE}$ ) in patients with patchy atrophy secondary to myopic macular degeneration (NCT02122159), but the study was withdrawn in 2016 and no results have been posted.

RPE cells obtained from human autologous somatic cells (hiPSCs) were used in a phase I CT in 2013 in Japan (UMIM000011929) in which the first patient improved without adverse effects, but the study was put on hold because oncogenic genetic mutations were found in the second patient, probably due to the documented genomic instability of iPSCs. The CT since resumed, using HLA-matched allogenic iPSCS-derived RPE cells in suspension compared with autologous iPSCs, the first being safer and more likely to succeed 
economically. The transplanted sheet remained intact and BCVA was stable one year after surgery, although cystoid macular edema was present. [56] More recently, another two ongoing CTs have commenced in England and the USA (NTC02464956) to test the efficiency of creating iPSC-derived RPE cells from the patient's own skin or blood. This trial started in 2015 in 10 patients with AMD and is not yet recruiting [57]. At the same time, many scientists are studying the safety concerns surrounding the iPSCs obtained through the reprogramming process.

Recently, a combination of gene and cell therapy has been implemented using the CRISPR/Cas9 system applied to the production of iPSCs with selective HLA gene disruption [58]. One example is a recent CT for a specific type of RP with mutations in disease-causing genes that affect RPE function (NCT0963154), aiming to restore RPE function and protect photoreceptors from degeneration at a relatively early stage.

However, the delivery strategy of a cell suspension might not be sufficient, and more complex reconstructed tissue formulations are probably required, both to improve functionality and to target pathological conditions with altered Bruch's membrane-like AMD. For clinical applications, Kamao et al. developed a protocol for an RPE monolayer sheet obtained from hiPSC-RPE cells without using any synthetic scaffold, but rather self-producing their basement membrane consisting of collagen IV and laminin. This was shown to be functional in vivo when used in neovascular AMD after the removal of the choroidal neovascularization, with no sign of rejection and no patients needing additional anti-VEGF injections. The major problem was the expense and extensive preparation time needed for each individual patient (more than 10 months) $[59,60]$. Likewise, more complex reconstructed tissue formulations have been proposed in order to improve functionality and replace the damaged Bruch's membrane in AMD using 3D bioengineered tissues amenable for regenerative medicine, developing RPE sheets or substrates to make the technical transfer more tolerable to the cells during surgery and to increase survival compared to cells in suspension, as well as increasing the chance of the cells forming an organized orientation tissue reminiscent of the endogenous cellular structure [61]. An example of this new strategy is a recruiting phase I/II CT (NCT02903576) that is trying to determine whether the surgical implantation of an hESC-derived RPE cell monolayer seeded onto a polymeric substrate versus hESC-derived RPE cell injections alone into the subretinal space are safe procedures. This has been planned in patients with dry AMD, disciform scarring due to wet AMD and Stargardt's disease. Thus, Kashani et al. have designed an implant using a scaffold, termed the California Project to Cure Blindness-Retinal Pigment Epithelium 1 (CPCB-RPE1), which consists of a polarized monolayer of hESC-derived RPE cells on an ultrathin synthetic parylene (plastic) substrate designed to mimic Bruch's membrane. This group has published data on a cohort of 16 patients with advanced dry AMD (NCT02590692), which demonstrate the technique's safety and suggest that it may improve visual function, since none of the implanted eyes showed the progression of vision loss, one eye improved by 17 letters and two eyes demonstrated improved fixation [62]. The group led by da Cruz et al. is investigating a similar RPE patch in severe exudative AMD as a part of The 
London Project to Cure Blindness (NCT03102138). Finally, a phase I CT used an engineered RPE patch comprising a fully differentiated hESC-derived RPE monolayer on a coated, synthetic basement membrane, delivered using a purpose-designed microsurgical tool into the subretinal space of one eye in two patients with severe exudative AMD. Only local immunosuppression was used long-term. The authors reported the successful delivery and survival of the RPE patch by means of biomicroscopy and optical coherence tomography (OCT), and a BCVA gain of 29 and 21 letters in the two patients, respectively, over 12 months. They also presented the preclinical surgical, cell safety and tumorigenicity studies, leading to the trial's approval [63].

\section{Photoreceptor Replacement}

To treat IRD, and mainly RP, it is necessary to replace dysfunctional or dead rods and cones, creating a therapeutic "slot" for cell therapies between gene therapy (for early stages of the disease) and retinal microchips (for advanced stages of the disease). One of the difficulties in treating advanced stages is that most of these conditions affect the entire retina. Replacing photoreceptors has been tried when these are the major cell type involved in retinal degeneration. In this case, the introduced precursors would have to form a polarized outer nuclear layer with the formation of light-sensitive outer segments, and then would have to reconnect synaptically with downstream retinal neurons in order to send information down the visual pathway.

To do this, various forms of transplant have been applied, including a fullthickness retina; photoreceptor sheets (sliced using a laser or vibratome); dissociated cells, including photoreceptors or the retinal progenitor cells (RPCs) that are able to produce them; and hPSC-derived cells. [64] Patients may also benefit from a combined RPE and photoreceptor transplant, but whether this would be a stepwise approach with RPE replacement followed by photoreceptor transplantation or whether the two could be transplanted together needs to be explored, as Zhu et al. showed that the survival of photoreceptor progenitor cells was increased when they were co-cultured with hESC-derived RPE [65].

The first publications on this issue indicated the potential benefit of transplanting fetal retinal cells or tissue in patients with retinal degeneration and its safety, but these grafts were limited due to ethical concerns and reduced availability [66]. Furthermore, the surgical techniques used to perform the subretinal transplantation of full-thickness retina or photoreceptor sheets are difficult to perform, and cell integration and synaptic re-connection are also challenging [67]. However, with the advent of well-established protocols to differentiate substantial quantities of retinal cells from hESCs and iPSCs, regenerative retinal therapies have become a practical goal in clinical practice [68].

RPCs have been demonstrated to become mature and express photoreceptor markers when injected into the subretinal space, and they are also able to integrate into the host inner retina and rescue degenerated photoreceptors [69]. RPCs and hESC-derived photoreceptor precursor cells have been shown to integrate into the host retina and improve light sensitivity, although the effect was reversed in months $[69,70]$. Another source could be hiPSC-derived photoreceptor precursors - results have demonstrated that adult fibroblast- 
derived iPSCs can differentiate into retinal precursors to be used for the transplantation and treatment of retinal degeneration diseases [71-73]. The main question is whether transplanted photoreceptors actually integrate. They may instead fuse with existing photoreceptors, since in recent years a phenomenon known as "material transfer" has been proposed, whereby biomaterial such as proteins and/or mRNA is transferred from donor to host photoreceptors, thereby restoring some visual function by rescuing remaining photoreceptor cells $[74,75]$. An important point is that more progress in preclinical studies is needed in order to better understand and optimize cell integration in order to plan future CTs.

An important CT is implementing the use of subretinally transplanted hRPCs derived from the fetal retina. This is a phase $\mathrm{l} /$ /la, open-label, prospective study aiming to test their safety and tolerability in patients with advanced RP, and has been sponsored by ReNeuron (NCT02464436). In addition, for RP a trial using hESC-derived-RPE cells is recruiting 10 patients to test the safety and efficacy of its subretinal transplantation technique (NCT03944239).

Siqueira et al. at the University of Sao Paulo have primarily investigated the use of autologous BMMSCs intravitreally injected to treat patients with advanced degenerative retinopathies (one RP patient and two affected by cone-rod dystrophy) in a phase I CT (NCT01068561), without detecting serious adverse events. In a phase II study, they started to confirm the efficacy of this technique (NCT1560715) in 20 RP patients, showing a transitory improvement of vision that lasted no longer than one year $[76,77]$. The same group has investigated the safety and effectiveness of their cell product in AMD and Stargardt's patients (NCT01518127).

In the case of IRD, patient-derived iPSCs carry pathogenic gene mutations that may affect the survival and function of autologous transplanted cells. Thus, the cell replacement strategy can utilize patient-specific photoreceptor precursor cells that have been genetically corrected through conventional gene therapy using viral vectors or via gene editing, using both the clustered regularly interspaced short palindromic repeats-associated protein 9 (CRISPR/Cas9) system or the transcription activator-like effector nucleases (TALEN) system $[78,79]$. However, the phenotypic correction of iPSCs is not efficient enough (because of transgene silencing), so it may be more advantageous to correct somatic cells "ex vivo" before reprogramming. The advantage of this approach is that it could be used to treat inherited retinal disorders, regardless of the clinical stage or prevalence of the disease, and of the size of the causative gene [80]. Further work is required to ensure safety regarding off-target mutations due to gene editing and mutagenesis that may occur during the derivation and differentiation of iPSCs, although despite these challenges, gene editing technology has made rapid advances and is a valuable tool in understanding and treating RD [81]. CRISPR/Cas9 can be also used to turn genes on, instead of snipping them via epigenetics, by modulating histone marks, rather than editing DNA sequences, thus obtaining improvements or the amelioration of symptoms. Nevertheless, some challenges remain before this can be implemented in the clinic [82]. Additionally, a drug-tunable gene therapy, which led to the expression of a neurotrophic factor-destabilization domain fusion 
protein, preserved cone vision in preclinical studies, suggesting its potential use against broad-spectrum RD and its possible use as an adjunct therapy along with stem-cell therapy [83]. In this respect, Cereso et al. used AAV2/5 as a carrying vector to effectively transduce iPSC-derived RPE cells from a choroideremia patient, thus illustrating the potential of patient iPSC-derived RPE cells to provide a proof-of-concept model for gene replacement when there is no an appropriate animal model [84]. Furthermore, Burnight et al. transduced patient-specific, iPSC-derived, photoreceptor precursor cells with lentiviral vectors carrying full-length CEP290 in order to correct a causing mutation of Leber's congenital amaurosis, which affects the cilia formation of the photoreceptors. Their results showed the expression of full-length transcripts and functional rescue of the ciliogenesis defect in patient cells [85]. Bassuk et al. used the CRISPR/Cas9 system to precisely repair an RPGR point mutation that causes X-linked RP (XLRP) [86]. Lastly, another CT using iPSCs to develop cell models of different retinal dystrophies is also recruiting (NCT03853252) to evaluate the efficiency of gene therapy approaches.

An additional approach to cell-based therapy is to introduce optical sensors into grafted photoreceptor cells to make them function stably and independently of the RPE [87]. Finally, mesenchymal stem cell-derived exosomes are also being tested in a clinical trial (NCT03437759) because they seem to the promote healing of large and refractory macular holes.

\section{Ganglion Cell Replacement and Cell Therapy for Optic Nerve Diseases (ONDs)}

Among the studies registered in ClinicalTrials.gov, only 18 are related to OND, and six have not shown results for a long time, so it is presumable that they have failed or have been interrupted (Table 1). The rest are phase I or II CTs related to a few diseases (Table 2). Three of them are focused on optic nerve atrophy, which is the end result of many pathologies with different pathogeneses. Four included patients with neuromyelitis optica (Devic's disease), an autoimmune disorder predominantly characterized by severe optic neuritis and transverse myelitis. For many years this disease was considered a variant of multiple sclerosis, but the discovery that most patients have autoantibodies against aquaporin-4 (AQP4) or NMO-IgG changed the understanding of the disease [88].

In one of the CTs, dominant optic atrophies and Leber's hereditary optic neuropathy (LHON) are included, although many other ocular pathologies are also included. This trial will be discussed below.

Three of the trials are focused on glaucoma. This disease has traditionally been viewed as a primary OND, in which the optic nerve is damaged as a result of high intraocular pressure (IOP). Glaucomatous optic neuropathy is characterized by significant death of RGCs. According to global surveys, the second leading cause of blindness after cataracts is glaucoma. But there is a substantial group of people (up to $20 \%$ ) with typical glaucomatous disc changes, progressive visual field defects and open anterior chamber angles associated with intraocular pressure (IOP) constantly below $21 \mathrm{mmHg}$, a condition known as normal tension glaucoma [89]. The main goal of glaucoma treatment is IOP reduction. The Early Manifest Glaucoma Trial showed that glaucoma progression was decreased by $10 \%$ with the reduction of each $\mathrm{mmHg}$ 
of IOP but according to the Collaborative Normal Tension Glaucoma Study Group, an IOP reduction of $30 \%$ is required to slow the progression of normal tension glaucoma-a goal that is difficult to achieve with the currently available glaucoma treatments [89]. Therefore, treatment should be ideally targeted at neuroprotection to improve the RGCs or optic nerve head function by means of drugs such as calcium channel blockers or by means of cell therapy [29]. In this case, cell transplantation is still at an early stage of preclinical study, compared with RPE or photoreceptor transplantation [29]. Finally, a study by our group is focused on the acute phases of acute non-arteritic anterior ischemic optic neuropathy [6].

Regarding the types of cells, six CTs use BMMSCs. Three of these-all of them directed at neuromyelitis optica-use a combination of a high dose of immunosuppressive therapy, followed by autologous hematopoietic cell transplantation.

Two CTs use encapsulated cell technology. They use ARPE19, a retinal pigmented human cell line, genetically modified to produce ciliary neurotrophic factor (CNTF). Cells are encapsulated in a semipermeable polymer capsule which is introduced into the vitreous cavity. The idea seems very attractive and in theory it would open up many possibilities. It was primarily designed for treating retinal degenerative diseases [90], but initial results in diseases such as RP did not show any clinically relevant benefit, and since 2013 there have been no novel results in retinal pathologies [91] associated with the use of this technology. The company now seems to be concentrating on glaucoma, although no results have yet been reported.

However, regarding CNTF, there is a question that must be investigated in depth and that is the action of this factor on the glia cells. At least the acute administration of CNTF appears to be related to glial reactivity, which would not be desirable in the context of diseases either of the retina or of the optic nerve [92].

Returning to the CT sponsored by our Eye Institute (NCT03173638), our hypothesis is that ischemic neuropathy can resemble an ischemic stroke, and it should be possible for there to be a series of ganglion cell axons in the socalled penumbra zone. Thus, some of the growth factors released by BMDMSC could "rescue" these fibers, minimizing the damage. Without the presence of growth factors released by mesenchymal stem cells, many of those axons in the "penumbra zone" will die and the functional damage will be greater. A differential fact, in comparison with other CTs, that may be of great relevance is that our cells are from allogeneic sources.

The so-called Stem Cell Ophthalmology Treatment Study (SCOTS) and SCOTS-2 (NCT01920867 and NCT03011541) are especially deserving of interest. They are considered the largest stem cell studies for ocular diseases [93]. The research subjects include dominant optic atrophy and LHON. As in our $\mathrm{CT}$, the stem cell approach is based on the use of BMDMSCs, but in this case the cells are of autologous origin. This is a multicentric study (involving the USA and the United Arab Emirates), and the principal investigators are using mesenchymal stem cells to take advantage of their neuroprotective effects, which have been reported in a variety of animal models of optic nerve damage [94]. Although they are able to differentiate into neurons and glial cells [95], the 
use of these cells in these CTs is based on their ability to release neurotrophic agents. These neuroprotective properties have been experimentally proven in retinal layers by our group [96,97]. In the SCOTS-2 CT, five patients with LHON reported improvements in visual acuity and peripheral vision. In 2019, in the first SCOTS report, six patients with dominant optic atrophy were included. Five of them experienced visual improvement. The authors speculated that mitochondrial transfer and neuroprotective exosome secretion from mesenchymal stem cells could contribute to this improvement [98]. Nevertheless, these results must be taken with caution, as there was great variability in the treated conditions, including degenerative, ischemic and physical damage of the retina and/or optic nerve. Moreover, the eyes were treated through the injection of BMMSCs, using many different routes of administration-retrobulbar; sub-Tenon and intravenous together, or a combination of retrobulbar, sub-Tenon, intravitreal and intravenous, making the interpretation of their results difficult and creating certain doubts about the quality of the methodology used in the study's design. Thus, the scientific basis of cell therapy in hereditary optic neuropathies is still under investigation and validation [93].

Regarding the topic of administration routes, those studies that have focused on hematopoietic cell transplantation have obviously used intravenous application, whereas the rest, with two exceptions, have used the intravitreal route. These exceptions are the already mentioned CTs NCT01920867 and NCT03011541, sponsored by the same company, MD Stem Cells (Coral Springs, Florida, USA). This is an interventional, non-masked, parallel, non-randomized clinical study, including several retinal conditions and optic nerve diseases (such as glaucoma, optic nerve compression, ischemic optic neuropathy and optic atrophy). The routes for the administration of cells include retrobulbar, subtenon, intravitreal and intravenous routes (alone or as supplements after other routes). The study started in 2016, and the expected date for completion is 2023.

A final reflection can be made on the possibility of using a multimodal therapy for diseases both of the retina and the optic nerve, which are complex and in which perhaps a single therapeutic approach would not work. In a recent paper [99], researchers from Brazil and Florida proposed an interesting combination of gene and cell therapy to increase RGC survival and their axon regrowth. This was an experimental study on a model of optic nerve crush, analyzing the neuroprotective and neuroregenerative potential of pigment epithelium-derived factor (PEDF) gene therapy alone and combined with human mesenchymal stem cell (hMSC) therapy. The authors found a synergistic effect in the combination of gene and cell therapy.

A final point concerns the safety of intravitreal stem cell injections. In a recent paper [100], researchers investigated the vascular outcomes after intravitreal mesenchymal stem cell (MSC) administration in rats, with or without damage to the neurovascular unit (transgenic rats). The authors used rat BMDMSCs and human ADMSCs and found that the intravitreal administration of MSCs induced cataract, retinal vaso-regression, activation of retinal glial cells and an inflammatory response even in normal rat eyes. Our group analyzed the safety 
of human bone marrow-derived MSCs [101] and these cells were safe and welltolerated when administered intravitreally at a dose of $15 \times 10^{6}$ cells $/ \mathrm{mL}$ in pigmented rabbits.

In view of the information analyzed in this review and comparing it with that obtained in our 2016 review [6], it does not appear that there has been much real progress in this field, and it seems that, in the very short term, none of the approaches that are being made in CTs seem to have been transferred to established clinical human treatments.

Ideal cell therapy involves several requisites, such as a source of viable cells, the management of cells under good manufacturing practices (GMPs), reliable delivery methods, long-term survival and functioning of grafted cells without severe adverse effects on the host, and of course a clear objective benefit in terms of the improvement or stabilization of the disease [16].

The main obstacles in this process are derived from the lack of adequacy of the host environment, and the time of use of the cells, which requires the production source close to be close to the clinical place of use. In addition, the short time of release of growth factors by the implanted cells forces us to look for alternatives such as genetically modified cells, which then pose other serious safety problems.

The rescue of RGCs in glaucomatous patients by means of the neuroprotective properties of pluripotent stem cells is a plausible and experimentally proven option. However, the difficulties mentioned above probably influence its very slow development from preclinical research to routine clinical use.

\section{Cell Therapy for Retinal Vascular Diseases}

In 2014, Park et al. injected for the first time autologous CD34+ BMMSCs into the vitreous cavities of six patients with retinal vascular occlusion or RD, finding a good safety profile that merits further exploration (NCT01736059) [102]. To date, autologous BMMSCs have been applied by means of intravenous infusion in 34 patients with DR (No. ChiCTR-ONC-16008055; chictr.org. cn). BCVA and central macular thickness, measured with OCT, improved without severe adverse events, mainly in the non-proliferative stage of the disease [103]. Another CT has proposed one intravitreal injection of bone marrow mononuclear stem cells in 30 patients with ischemic retinopathy, including DR with severe loss of retinal capillaries (NCT01518842). This trial is active but not recruiting. Furthermore, a phase I/II, prospective, randomized, sham-controlled, double-masked CT (NCT03981549) is ongoing, aiming to determine whether intravitreal autologous CD34+ stem cell therapy is safe, feasible and potentially beneficial in minimizing or reversing vision loss in eyes with ischemia due to central retinal vein occlusion. Lastly, the combination of CD34+CD45+ cells derived from iPSCs with iPSCs derived from the mesoderm (vascular wallderived progenitor cells or ECFCs) administered into the vitreous cavity is being evaluated in a clinical trial, assessing their potential beneficial effect in preventing microvascular complications in DR (NCT03403699) due to their antioxidative and anti-inflammatory effects. 
Finally, a CT intending to evaluate the function of serum exosomal miRNA in the pathogenesis of DR is ongoing (NCT03264976) but not yet recruiting patients [104]. According to the available information, it seems that stem cellderived exosomes may play an important role in $\mathrm{RD}$ treatment in the future.

\section{Challenges}

Several issues remain to be solved concerning the clinical translation of cellbased therapies, including (1) the ability to enrich for specific retinal subtypes; (2) cell survival; (3) cell delivery, which may need to incorporate a scaffold to induce correct cell polarization, which increases the size of the retinotomy in surgery and, therefore, the chance of severe complications compared to the delivery of isolated cells; (4) the need to induce retinal detachment to perform the subretinal placement of the transplanted cell, which could disrupt the first synapse of the visual pathway, which is thought to affect larger areas outside the iatrogenic detachment; and (5) the evaluation of the risk of tumor formation caused by undifferentiated stem cells and prolific progenitor cells, which increases when using genome-integrating viruses or gene editing to produce iPSCs because this can cause insertional mutagenesis and unpredictable genetic dysfunction and some transcription factors may have oncogenic properties [5].

The development of surgical techniques for delivering the cells to the right place is one of these challenges. Intravitreal injections have been used, as they are a common procedure in retina patient clinics and are associated with few complications. However, with this route of administration, the concern is that the host retina, mainly the inner limiting membrane, may act as a barrier and prevent the transplanted cells from migrating and integrating into the retinal tissue in the correct location [105]. Therefore, subretinal transplantation is the more commonly used technique when trying to obtain cell replacement, as the cells are delivered to the intended location and therefore better integration and differentiation is observed. However, this is a complex surgical procedure, requiring a skilled retinal surgeon with experience in subretinal surgery, as it has a high risk of surgical complications, including hemorrhage, PVR, graft dislocation and neovascularization [106,107]. If more than one type of cell is needed to restore the natural retinal cell layers, the question will then be whether the layers should be transplanted sequentially or if a retinal complex including the necessary layers would be optimal for the restoration of visual function. When using a cell sheet or an RPE-photoreceptor-scaffold complex, a subretinal approach would be especially necessary, since transplants of this size could not traverse the inner retina, and a purpose-designed microsurgical tool has been proposed to perform these transplants via the suprachoroidal approach, as we have already mentioned [63].

Furthermore, contact with the RPE is essential for photoreceptor cells to properly function. Therefore, new strategies should be found to prevent rosette formation, like transplanting photoreceptors and RPE at the same time [48]. Other attempt to facilitate efficient network formation with host retinal cells is to seed purified photoreceptor cells onto biomaterial sheets and then to transplant them [108]. 
It is also important to point out that cell survival and transplantation success are determined also by the extent of immune rejection, although we would be working in a relatively immune-privileged site [109]. ESCs do not express major histocompatibility complex (MHC) II and only a low level (although upregulated) of $\mathrm{MHC}$ I after transplantation [110]. iPSC-derived cells show less of an immune response [111], but produce an immune response when retroviruses are used to reprogram them [29]. Finally, MHC matching may be beneficial for successful allogeneic stem cell transplantation [112]. All these aspects will be crucial in order to establish the optimal immunosuppression regime for future clinical applications. Moreover, the Center for iPS Cell Research and Application (CiRA) started offering iPSCs stocks for regenerative medicine in 2015, based on the idea that only 10 cell lines carry the three most frequent HLA homologous loci (HLA-A, -B and -DR), thus reducing the possibility of rejection [113]. Therefore, a CT recruited patients suffering from RPE atrophy, who were transplanted with this product without needing systemic immunosuppression, and although one patient showed mild signs of rejection, this was well controlled through the local administration of steroids. However, it resulted in an insufficient number of cells being delivered to the targeted area, which is another problem that should be addressed [114].

On the other hand, future research in regenerative medicine for vascular ischemic retinal diseases must focus on the following issues-(1) whether endothelial precursor cells or MSCs derived from cord blood or pluripotent sources are more pluripotent and therapeutic than adult cells; (2) although adult stem cell therapies are in early I/Ila phase CTd, efficacy and safety results are still pending, and there is a long way to go before their findings can be applied to clinical practice; (3) understanding the interplay between various precursor cells is important in developing the ideal cell therapy for vascular regeneration, since the optimal cell therapy may involve a combination of stem cells or precursor cells; (4) pharmacologic methods aiming to overcome the potential host factors may enhance the regenerative potential of stem cells [115]; (5) understanding the molecular basis for the regenerative effect of stem cells in retinal vascular conditions might shed light on new pharmacologic or genetic approaches to treating retinal vascular disorders and new approaches to enhancing the therapeutic effects of currently available stem cell therapies [116].

As mentioned, the main challenge in OND is the maintenance of RGCs and stimulating the re-growth of their axons [117]. Optic nerve regeneration can be experimentally induced through different approaches, such as by delivering neurotrophic factors, increasing ocular inflammation and manipulating genes targeting growth-related inhibitors, such as phosphatase and tensin homolog (PTEN), Kruppel-like family (KLF) transcription factors and the suppressor of cytokine signaling 3 (SOCS3) [9]. Interestingly, many of these pro-regenerative pathways are at least indirectly associated with tumor growth, raising concerns about the clinical feasibility of their manipulation [118]. In addition, complex combinatorial approaches are still far from translation.

In 2019, Mesentier et al. [119] showed that intravitreally injected BMMCs promote RGC survival and regeneration after optic nerve crush but RGC survival declined over time. Therefore, one of the challenges is how to maintain 
the neuroprotective effect over time, especially in diseases in which the etiological treatment is not addressed. The same authors have demonstrated, using an optic nerve crush model, that the intravitreal injection of MSCs sustained RGC neuroprotection and long-distance regeneration, with transient target reconnection, but also with the progressive loss of the axon regenerative effect-an event that is not solely attributed to the clearance of MSCs but also to a limitation of cell therapy alone in achieving permanent neuronal reconnection to its targets. Thus, they suggest that the combination of MSCs or of their secretome with additional therapeutic approaches is more likely to sustain therapeutic effects for a longer time.

The lack of endogenous $R G C$ replacement in mammals differs from what happens in fish and amphibians, which add new RGCs throughout their lifespan, a feature that is thought to arise at least in part from the presence of a specific proneural transcriptional factor, Ascl1, made by retinal Müller glia in cold blooded vertebrates but not by mammalian Müller glia. Three general approaches to replacing RGCs include (i) syngeneic transplantation of adult induced pluripotent stem cells (iPSs) that have been programmed to assume RGC phenotypes, (ii) allogeneic transplantation of RGCs from healthy eyes into host eyes, and (iii) possible reprogramming of endogenous Müller glia into RGCs. Thus, the isolation of RGCs from the retinas of recently deceased humans for transplantation into recipient humans may actually represent a clinically viable strategy for curing otherwise irreversible forms of blindness [10]. As mentioned in the retinal diseases section, another approach could be the possible use of exosomes. Recent evidence has shown that MSCs secrete exosomes, membrane-enclosed vesicles (30-100 nm) containing proteins, mRNA and miRNA, which can be delivered to nearby cells. A recent experimental study in a rat optic nerve crush model demonstrated that exosomes from BMMSCs showed neuroprotective and neuritogenic effects [119]. In this model, BMSC-derived exosomes promoted statistically significant survival of RGCs and regeneration of their axons, while partially preventing RGC axonal loss and RGC dysfunction, opening a treatment possibility as a cell-free therapy for traumatic optic nerve disease, which nevertheless requires further confirmation.

Finally-and since some of the current CTs are directed at the involvement of the optic nerve in multiple sclerosis - it is worth reviewing an experimental approach that may be interesting. Recently, Gramlich et al. [120] aimed to determine the efficacy of MSC therapy on rescuing the visual system in the experimental autoimmune encephalomyelitis (EAE) model of multiple sclerosis (MS). Systemic MSC treatment (intraperitoneally) was found to positively affect RGC function and survival in EAE mice.

\section{Conclusions}

In summary, much progress has been made towards translating stem/progenitor cell technology into optimized therapies for retinal and optic nerve diseases, but the road to the clinic will be undeniably long. More defined differentiation protocols are required to improve efficiency and to obtain highquality enriched retinal cells at the desire state. Notably, insights into human 
retinal development with the advent of 3D cell culture techniques that mimic in vivo development may help in this regard. Moreover, the genetic modification of stem cells may prove to be a viable approach to generating specific populations of retinal cells that are able to produce some desirable cell products or to be used after correcting a disease-causing mutation. In addition, stem/progenitor cell therapies have already entered early-stage CTs and have demonstrated safety and some indicators of efficacy. Furthermore, the challenge of the immune rejection of transplants needs to be addressed. Currently, stem/progenitor cell therapies for retinal diseases still have some drawbacks, such as inhibition of proliferation and/or differentiation in vitro (with the exception of the RPE) and limited long-term survival and functioning of grafts in vivo. Despite these challenges, stem/progenitor cells represent the most promising strategy for retinal and optic nerve disease treatment in the near future, as therapeutic strategies assisted by gene techniques, neuroprotective compounds and artificial devices can be applied to fulfil clinical needs. Finally, the collaboration of various experts in engineering, cell biology, genetics and clinical medicine is essential for the development of successful cell therapies.

Supplementary Materials: None.

Author Contributions: R.M.C-M. and J-C.P. contributed to the conceptualization and methodology; R.M.C-M., S.P.I. and J-C.P., to writingoriginal draft preparation; and R.M.C-M., to final supervision and editing. All authors have read and agreed to the published version of the manuscript.

Funding: None.

Institutional Review Board Statement: The study was conducted according to the guidelines of the Declaration of Helsinki.

Informed Consent Statement: Not applicable.

Data Availability Statement: Not applicable.

Acknowledgments: None.

Conflicts of Interest: The authors declare no conflicts of interest.

\section{References}

1.- de Jong, P.T. Age-related macular degeneration. N Engl J Med. 2006, 355,1474-1485. [PMID: 17021323] [doi: 10.1056/NEJMra062326]

2.- Ferrari, S.; Di lorio, E.; Barbaro, V.; Ponzin, D.; Sorrentino, F.S.;

Parmeggiani, F. Retinitis pigmentosa: genes and disease mechanisms. Curr Genomics. 2011,12, 238-249. [PMID: 22131869] [doi:

$10.2174 / 138920211795860107]$

3.- Osborne, N.N.; Casson, R.J.; Wood, J.P.; Chidlow, G.; Graham, M.; Melena,

$J$. Retinal ischemia: mechanisms of damage and potential therapeutic

strategies. Prog Retin Eye Res. 2004, 23, 91-147. [PMID: 14766318] [doi:

10.1016/j.preteyeres.2003.12.001] 
4.- Barber, A. A new view of diabetic retinopathy: a neurodegenerative disease of the eye. Prog Neuro-Psychopharmacol Biol Psychiatry. 2003, 27, 283-290. [doi: 10.1016/S0278-5846(03)00023-X]

5.- Zarbin, M. Cell-Based Therapy for Retinal Disease: The New Frontier. Methods Mol Biol. 2019, 1834, 367-381. [PMID: 30324455] [doi: 10.1007/978-14939-8669-9_23]

6.- Labrador-Velandia, S.; Alonso-Alonso, M.L.; Alvarez-Sanchez, S.; GonzálezZamora, J.; Carretero-Barrio, I.; Pastor, J.C.; Fernandez-Bueno, I.; Srivastava, G.K. Mesenchymal stem cell therapy in retinal and optic nerve diseases: An update of clinical trials. World J Stem Cells. 2016, 8, 376-383. [PMID: 27928464] [PMCID: PMC5120242] [doi: 10.4252/wjsc.v8.i11.376] 7.- Fu, L.; Kwok, S.S.; Chan, Y.K.; Ming Lai, J.S.; Pan, W.; Nie, L.; Shih, K.C. Therapeutic Strategies for Attenuation of Retinal Ganglion Cell Injury in Optic Neuropathies: Concepts in Translational Research and Therapeutic Implications. Biomed Res Int. 2019, 11, 2019:8397521. [PMID: 31828134] [PMCID: PMC6885158] [doi: 10.1155/2019/8397521]

8.- DeBusk, A.; Moster. M.L. Gene therapy in optic nerve disease. Curr Opin Ophthalmol. 2018, 29, 234-238. [PMID: 29538182] [doi:

10.1097/ICU.0000000000000473]

9.- Moore, D.L.; Goldberg, J.L. Four steps to optic nerve regeneration. J Neuroophthalmol. 2010, 30, 347-60. [PMID: 21107123] [doi:

10.1097/WNO.0b013e3181e755af]

10.- Laha, B.; Stafford, B.K.; Huberman, A.D. Regenerating optic pathways from the eye to the brain. Science. 2017, 356, 1031-1034. [PMID: 28596336]

[PMCID: PMC6333302] [doi: 10.1126/science.aal5060]

11.- Chun, B.Y.; Cestari, D.M. Advances in experimental optic nerve regeneration. Curr Opin Ophthalmol. 2017, 28, 558-563. [PMID: 28795960] [doi: 10.1097/ICU.0000000000000417]

12.- Cenni, M.C.; Bonfanti, L: Martinou, J.C.; Ratto, G.M.; Strettoi, E.; Maffei, L. Long-term survival of retinal ganglion cells following optic nerve section in adult bcl-2 transgenic mice. Eur J Neurosci. 1996, 8, 1735-1745. [PMID: 8921264] [doi: 10.1111/j.1460-9568.1996.tb01317.x]

13.- Bonfanti, L.; Strettoi, E.; Chierzi, S.; Cenni, M.C.; Liu, X.H.; Martinou, J-C.; Maffei, L.; Rabacchi, S.A. Protection of retinal ganglion cells from natural and axotomy-induced cell death in neonatal transgenic mice overexpressing bcl-2. $J$ Neurosci. 1996, 16, 4186-4194. [PMID: 8753880] [PMCID: PMC6578989] [doi: 10.1523/JNEUROSCI.16-13-04186.1996]

14.- Maes, M.E.; Schlamp, C.L.; Nickells, R.W. BAX to basics: How the BCL2 gene family controls the death of retinal ganglion cells. Prog Retin Eye Res.

2017, 57, 1-25. [PMID: 28064040] [PMCID: PMC5350025] [doi:

10.1016/j.preteyeres.2017.01.002]

15.- Puertas-Neyra, K.; Usategui-Martín, R.; Coco, R.M.; Fernandez-Bueno, I. Intravitreal stem cell paracrine properties as a potential neuroprotective therapy for retinal photoreceptor neurodegenerative diseases. Neural Regen Res. 2020, 15,1631-1638. [doi: 10.4103/1673-5374.276324]

16.- Shen, Y. Stem cell therapies for retinal diseases: from bench to bedside. $J$ Mol Med (Berl). 2020, 98, 1347-1368. [PMID: 32794020] [doi: 10.1007/s00109020-01960-5] 
17.- Huang, S.S. Future vision 2020 and beyond. 5 critical trends in eye research. Asia Pac J Ophthalmol (Phila). 2020, 9, 180-185. [doi: 10.1097/APO.0000000000000299]

18.- Kannabiran, C.; Mariappan, I. Therapeutic avenues for hereditary forms of retinal blindness. J Genet. 2018, 97, 341-352. [PMID: 29666355]

19.- Salero, E.; Blenkinsop, T. A.; Corneo, B.; Harris, A.; Rabin, D.; Stern, J.H.; Temple, S. Adult human RPE can be activated into a multipotent stem cell that produces mesenchymal derivatives. Cell Stem Cell. 2012, 10, 88-95. [PMID: 22226358] [doi: 10.1016/j.stem.2011.11.018]

20.- Wang, Y.; Tang, Z.; Gu, P. Stem/progenitor cell-based transplantation for retinal degeneration: a review of clinical trials. Cell Death Dis. 2020, 11, 793.

[PMID: 32968042] [PMCID: PMC7511341] [doi: 10.1038/s41419-020-02955-3] 21.- Tang, Z.; Zhang, Y.; Wang, Y.; Zhang, D.; Shen, B.; Luo, M.; Gu, P.

Progress of stem/progenitor cell-based therapy for retinal degeneration. $J$ Transl Med. 2017, 15, 99. [PMID: 28486987] [PMCID: PMC5424366] [doi: 10.1186/s12967-017-1183-y]

22.- Caplan, A.; Deniis, J. Mesenchymal stem cells as trophic mediators. J Cell Biochem. 2006, 98, 1076-1084. [doi: 10.1002/jcb.20886].

23.- Chamberlian ,G.; Fox, J.; Ashton, B.; Middleton, J. Concise review: mesenchymal stem cells: their phenotype, differentiation capacity, immunological features, and potential for homing. Stem Cells. 2007, 25, 27392749. doi: 10.1634/stemcells.2007-0197

24.- Megaw, R.; Dhillon, B. Stem cell therapies in the management of diabetic retinopathy. Curr Diab Rep. 2014, 14, 498. [doi: 10.1007/s11892-014-0498-9] 25.- Tang, Z.; Zhang, Y.; Wang, Y.; Zhang, D.; Shen, B.; Luo, M.; Gu, P. Progress of stem/progenitor cell-based therapy for retinal degeneration. $J$ Transl Med. 2017, 15, 99. [doi: 10.1186/s12967-017-1183-y]

26.- Alvarez-Palomo, A.B.; McLenachan, S.; Chen, F.K.; Da Cruz, L.; Dilley, R.J.; Requena, J.; Lucas, M.; Lucas, A.; Drukker, M.; Edel, M.J. Prospects for clinical use of IPCS. Fibrogenesis Tissue Repair, 2015, 8, 9. [doi:

10.1186/s13069-015-0026-9]

27.- Mandai, M.; Kurimoto, Y.; Takahashi, M. Autologous induced stem-cellderived retinal cells for macular degeneration. $N$ Engl J Med. 2017, 377, 792793. [doi: 10.1056/NEJMoa1608368]

28.- Nakano, T.; Ando, S.; Takata, N.; Kawada, M.; Muguruma, K.; Sekiguchi, K.; Saito, K.; Yonemura, S.; Eiraku, M.; Sasai, K. Self-formation of optic cups and storable stratified neural retina from human ESCs. Cell Stem Cell. 2012, 10, 771-785. [doi: 10.1016/j.stem.2012.05.009]

29.- Zhao, C.; Wang, Q.; Temple, S. Stem cell therapies for retinal diseases: recapitulating development to replace degenerated cells. Development. 2017, 144, 1368-1381. [doi:10.1242/dev.133108]

30.- Reichman, S.; Slembrouck, A.; Gagliardi, G.; Chaffiol, A.; Terray, A.; Nanteau, C.; Potey, A.; Belle. M.; Rabesandratana, O.; Duebel, J.; Orieux, G.; Nandrot, E.F.; Sahel, J.A.; Goureau, O. Generation of Storable Retinal Organoids and Retinal Pigmented Epithelium from Adherent Human iPS Cells in Xeno-Free and Feeder-Free Conditions. Stem Cells. 2017, 35, 1176-1188. [doi: 10.1002/stem.2586] [PMID: 28220575]

31.- Tanaka, T.; Yokoi ,T.; Tamalu, F.; Watanabe, S-I.; Nishina S.; Azuma, N. Generation of retinal ganglion cells with functional axons from human induced pluripotent stem cells. Sci Rep. 2015, 5, 8344. [doi: 10.1038/srep08344] 
32.- Kim, H.; Kim, J.J.; Yoon, Y:S. Emerging therapy for diabetic neuropathy: cell therapy targeting vessels and nerves. Endocr Metab Immune Disord Drug Targets. 2012, 12, 168-178. [doi: 10.2174/187153012800493486] 33.- Park, S.S. Cell Therapy Applications for Retinal Vascular Diseases: Diabetic Retinopathy and Retinal Vein Occlusion. Invest Ophthalmol Vis Sci. 2016, 57, ORSFj1-ORSFj10. [doi:10.1167/iovs.15-17594] 34.- Asahara, T.; Murohara, T.; Sullivan, A.; Silver, M.; van der Zee, R.; Li, T.; Witzenbichler, B.; Schatteman, G.; Isner J.M. Isolation of putative progenitor endothelial cells for angiogenesis. Science. 1997, 275, 964-967. [doi:

10.1126/science.275.5302.964]

35.- Kim, H.; Kim, J.J.; Yoon, Y.S. Emerging therapy for diabetic neuropathy: cell therapy targeting vessels and nerves. Endocr Metab Immune Disord Drug Targets. 2012, 12, 168-178. [doi: 10.2174/187153012800493486]

36.- Mackie, A.R.; Losordo, D.W. CD34 positive stem cells in the treatment of heart and vascular disease in human beings. Tex Heart Inst J. 2011, 38, 474485. [PMID: 22163120] [PMCID: PMC3231531]

37.- Caballero, S.; Sengupta, N.; Afzal, A.; Chang, K.H.; Li Calzi, S.; Guberski, D. L.; Kern, T. S.; Grant, M. B. Ischemic vascular damage can be repaired by healthy, but not diabetic, endothelial progenitor cells. Diabetes, 2007, 56, 960 967. [doi: 10.2337/db06-1254]

38.- Goldenberg-Cohen, N.; Avraham-Lubin, B.C.; Sadikov, T.; Askenasy, N. Effect of co-administration of neuronal growth factors on neuroglial differentiation of bone marrow-derived stem cells in the ischemic retina. Invest Ophthalmol Vis Sci. 2014, 55, 502-512. [doi: 10.1167/iovs.13-12223]

39.- Medina, R.J.; O’Neill, C.L.; Humphreys, M.W.; Gardiner, T.A.; Stitt, A.W. Outgrowth endothelial cells: characterization and their potential for reversing ischemic retinopathy. Invest Ophthalmol Vis Sci. 2010, 51, 5906-5913. [doi: 10.1167/iovs.09-4951]

40.- Mendel, T.A.; Clabough, E.B.; Kao, D.S.; Demidova-Rice, T.N.; Durham, J.T.; Zotter, B.C.; Seaman, S.A.; Cronk, S.M.; Rakoczy, E. P.; Katz, A.J.; Herman, I.M.; Peirce, S. M.; Yates, P.A. Pericytes derived from adipose-derived stem cells protect against retinal vasculopathy. PLoS One. 2013, 8, e65691. [doi: 10.1371/journal.pone.0065691] 41.- Prasain, N.; Lii M.R.; Vemula, S.; Meador, J.L.; Yoshimoto, M.; Ferkowicz, M.J.; Fett, A.; Gupta, M.; Rapp, B.M.; Saadatzadeh, M.R.; Ginsberg, M.; Elemento, O.; Lee, Y.; Voytik-Harbin, S.L.; Chung, H.M.; Hong, K.S.; Reid, E.; O'Neill, C.L.; Medina, R.J.; Stitt, A. W.; Murphy, M.P.; Rafii, S.; Broxmeyer, H.E.; Yoder, M. C. Differentiation of human pluripotent stem cells to cells similar to cord-blood endothelial colony-forming cells. Nat Biotechnol. 2014, 32, 11511157. [doi: 10.1038/nbt.3048]

42.- Park, T.S.; Bhutto, I.; Zimmerlin, L.; Huo JS, Nagaria P, Miller D, Rufaihah AJ, Talbot C, Aguilar J, Grebe R, Merges C, Reijo-Pera R, Feldman RA, Rassool F, Cooke J, Lutty G, Zambidis ET. V Vascular progenitors from cord blood-derived induced pluripotent stem cells possess augmented capacity for regenerating ischemic retinal vasculature. Circulation. 2014, 129, 359-372. [PMID: 24163065] [PMCID: PMC4090244] [doi: 10.1161/CIRCULATIONAHA.113.003000]

43.- Moisseiev, E.; Anderson, J.D.; Oltjen, S.; Goswami, M.; Zawadzki, R.J.; Nolta, J.A.; Park, S.S. Protective Effect of Intravitreal Administration of 
Exosomes Derived from Mesenchymal Stem Cells on Retinal Ischemia. Current eye research. 2017, 42, 1358-1367. [doi: 10.1080/02713683.2017.1319491] 44.- Safwat, A.; Sabry, D.; Ragiae, A.; Amer, E.; Mahmoud, R.H.; Shamardan, R.M. Adipose mesenchymal stem cells-derived exosomes attenuate retina degeneration of streptozotocin-induced diabetes in rabbits. J Circ Biomark. 2018, 7, 1849454418807827. [doi: 10.1177/1849454418807827] 45.- Alexander, P.; Thomson, H.A.; Luff, A.J.; Lotery, A.J. Retinal pigment epithelium transplantation: concepts, challenges, and future prospects. Eye (Lond). 2015, 29, 992-1002. [PMID: 26043704] [PMCID: PMC4541358] [doi: 10.1038/eye.2015.89]

46.- Binder, S.; Stolba, U.; Krebs, I.; Kellner, L.; Jahn, C.; Feichtinger, H.; Povelka, M.; Frohner, U.; Kruger, A.; Hilgers, R. D.; Krugluger, W.

Transplantation of autologous retinal pigment epithelium in eyes with foveal neovascularization resulting from age-related macular degeneration: A pilot study. Am J Ophthalmol. 2002, 133, 215-225. [doi: 10.1016/s00029394(01)01373-3]

47.- Li, L.X.; Turner, J.E. Inherited retinal dystrophy in the RCS rat: Prevention of photoreceptor degeneration by pigment epithelial cell transplantation. Exp Eye Res. 1988, 47, 911-917. [doi: 10.1016/0014-4835(88)90073-5] 48.- Uyama, H.; Mandai, M.; Takahashi, M. Stem Cell-Based Therapies for Retinal Degenerative Diseases: Current Challenges in the Establishment of New Treatment Strategies. Dev Growth Differ. 2020, 63, 59-71. [PMID: 33315237] [doi: 10.1111/dgd.12704]

49.- Satarian, L.; Nourinia, R.; Safi, S.; Kanavi, M.R.; Jarughi, N.; Daftarian, N.; Arab, L.; Aghdami, N.; Ahmadieh, H.; Baharvand, H. Intravitreal injection of bone marrow mesenchymal stem cells in patients with advanced retinitis pigmentosa; a safety study. J Ophthalmic Vis Res. 2017, 12, 58-64. [doi: 10.4103/2008-322X.200164]

50.- Egypt. Al-Azhar University. Safety study of use of autologuous bone marrow derived stem cell in treatment of age related macular degeneration. https://clinicaltrials.gov/ct2/show/study/NCT02016508. Accessed May 2, 2021. 51.- Schwartz, S.D.; Hubschman, J-P.; Heilwell, G.; Franco-Cardenas, V.; Pan; C.K.; Ostrick, R.M.; Mickunas, E.; Gay, R.; Klimanskaya, I.; Lanza, R. Embryonic stem cell trials for macular degeneration: a preliminary report. Lancet. 2012, 379, 713-720. [doi: 10.1016/S0140-6736(12)60028-2] 52.- Schwartz, S.; Regillo, C.; Lam, B.; Eliott, D.; Rosenfeld, P.; Gregori, N.; Hubschman, J-P.; Davis, J.; Heilwell, G.; Spirn, M. Human embryonic stem cell-derived retinal pigment epithelium in patients with age related macular degeneration and Stargardt's macular dystrophy: follow-up of two open-label phase 1/2 studies. Lancet, 2015, 385, 509-516. [doi: 10.1016/S01406736(14)61376-3]

53.- Mehat, M.S.; Sundaram, V.; Ripamonti, C. Transplantation of Human Embryonic Stem Cell-Derived Retinal Pigment Epithelial Cells in Macular Degeneration. Ophthalmology. 2018, 125, 1765-1775. [doi:

10.1016/j.ophtha.2018.04.037]

54- Song WK, Park KM, Kim HJ, Lee, J. H., Choi, J., Chong, S. Y., Shim, S. H., Del Priore, L. V., \& Lanza, R.. Treatment of macular degeneration using embryonic stem cell-derived retinal pigment epithelium: preliminary results in Asian patients. Stem Cell Reports. 2015, 4, 860-872. [doi:10.1016/j. stemcr.2015.04.005] 
55.- Liu, Y.; Xu, H.W.; Wang, L.; Li, S.Y.; Zhao, C.J.; Hao, J.; Li, Q.Y.; Zhao, T.T.; Wu, W.; Wang, Y.; Zhou, Q.; Qian, C.; Wang, L.; Yin, Z.Q. Human embryonic stem cell-derived retinal pigment epithelium transplants as a potential treatment for wet age-related macular degeneration. Cell Discov. 2018, 4, 50. [doi: 10.1038/s41421-018-0053-y]

56.- Mandai, M.; Watanabe, A.; Kurimoto, Y.; Hirami, Y.; Morinaga, C.; Daimon, T.; Fujihara, M.; Akimaru, H.; Sakai, N.; Shibata, Y.; Terada, M.; Nomiya, Y.; Tanishima, S.; Nakamura, M.; Kamao, H.; Sugita, S.; Onishi, A.; Ito, T.; Fujita, K.; Kawamata, S.; Go, M.J.; Shinohara, C.; Hata K-I.; Sawada, M.; Yamamoto, M.; Ohta, S.; Ohara, Y.; Yoshida, K.; Kuwahara, J.; Kitano, Y.;Amano, N.; Umekage, M.; Kitaoka, F.; Tanaka, A.; Okada, C.; Takasu, N.; Ogawa, S.; Yamanaka, S.; Takahashi, M. Autologous induced stem-cell-derived retinal cells for macular degeneration. New Engl J Med. 2017, 376, 1038-1046. [doi: 10.1056/NEJMoa1608368]

57.- Production of iPSC Derived RPE Cells for Transplantation in AMD.

ClinicalTrials.gov. Identifier: NCT02464956. Last Updated: June 8, 2015. Last acceded $2^{\text {nd }}$ May 2021.

58.- Xu, H.; Wang, B.; Ono, M.; Kagita, A.; Fujii, K.; Sasakawa, N.; Ueda, T.; Gee, P.; Nishikawa, M.; Nomura, M.; Kitaoka, F.; Takahashi, T.; Okita, K.; Yoshida, Y.; Kaneko, S.; Hotta, A. Targeted Disruption of HLA Genes via CRISPR-Cas9 Generates iPSCs with Enhanced Immune Compatibility. Cell Stem Cell. 2019; 24, 566-578.e7. [PMID: 30853558] [doi: 10.1016/j.stem] 59.- Maeda, T.; Lee, M.J.; Palczewska, G.; Marsili, S.; Tesar, P.J.; Palczewski, K.; Takahashi, M.; Maeda, A. Retinal pigmented epithelial cells obtained from human induced pluripotent stem cells possess functional visual cycle enzymes in vitro and in vivo. J Biol Chem. 2013, 288, 34484-34493. [PMID: 24129572] [PMCID: PMC3843063] [doi: 10.1074/jbc.M113.518571]

60.- Kamao, H.; Mandai, M.; Okamoto, S.; Sakai, N.; Suga, A.; Sugita, S., Kiryu, J.; Takahashi, M.. Characterization of Human Induced Pluripotent Stem CellDerived Retinal Pigment Epithelium Cell Sheets Aiming for Clinical Application. Stem Cell Reports. 2014, 2, 205-218. [doi:10.1016/j.stemcr.2013.12.007] 61.- Ben M'Barek, K.; Habeler, W.; Monville, C. Stem Cell-Based RPE Therapy for Retinal Diseases: Engineering 3D Tissues Amenable for Regenerative Medicine. Adv Exp Med Biol. 2018, 1074, 625-632. [PMID: 29721996] [doi: 10.1007/978-3-319-75402-4_76]

62.- Kashani, A.H.; Uang, J.; Mert, M.; Rahhal, F.; Chan, C.; Avery, R.L.; Dugel, P.; Chen, S.; Lebkowski, J.; Clegg, D.O.; Hinton, D.R.; Humayun, M.S. Surgical Method for Implantation of a Biosynthetic Retinal Pigment Epithelium Monolayer for Geographic Atrophy: Experience from a Phase 1/2a Study. Ophthalmol Retina. 2020; 4, 264-273. [PMID: 31786135] ]doi: 10.1016/j.oret.2019.09.017] 63.- da Cruz, L.; Fynes, K.; Georgiadis, O.; Kerby, J.; Luo, Y.H.; Ahmado, A.; Vernon, A., Daniels, J.T.; Nommiste, B.; Hasan, S.M.; Gooljar, S.B.; Carr, A.F.; Vugler, A.; Ramsden, C.M.; Bictash, M.; Fenster, M.; Steer, J.; Harbinson, T.; Wilbrey, A.; Tufail, A.; Feng, G.; Whitlock, M.; Robson, A.G.; Holder, G.E.; Sagoo, M.S.; Loudon, P.T.; Whiting, P.; Coffey, P.J. Phase 1 clinical study of an embryonic stem cell-derived retinal pigment epithelium patch in age-related macular degeneration. Nat Biotechnol. 2018, 36, 328-337. [doi: 10.1038/nbt.4114] 
64.- Zhao, C.; Wang, Q.; Temple, S. Stem cell therapies for retinal diseases: recapitulating development to replace degenerated cells. Development. 2017, 144, 1368-1381. [doi:10.1242/dev.133108]

65- Zhu, D.; Deng, X.; Spee, C.; Sonoda, S.; Hsieh, C.L.; Barron, E.; Barron, E.; Pera, M.; Hinton, D.R. Polarized secretion of PEDF from human embryonic stem cell-derived RPE promotes retinal progenitor cell survival. Invest Ophthalmol Vis Sci. 2011, 52, 1573-1585. [doi: 10.1167/iovs.10-6413] 66.- Radtke, N.D.; Aramant, R.B.; Seiler, M.J.; Petry, H.M,; Pidwell, D. Vision change after sheet transplant of fetal retina with retinal pigment epithelium to a patient with retinitis pigmentosa. Arch Ophthalmol. 2004, 122, 1159-1165. [PMID: 15302656] [doi: 10.1001/archopht.122.8.1159]

67.- Aramant, R.B.; Seiler, M.J. Progress in retinal sheet transplantation. Prog Retin Eye Res. 2004, 23, 475-494. [PMID: 15302347] [doi:

10.1016/j.preteyeres.2004.05.003]

68.- Gonzalez-Cordero, A.; West, E.L.; Pearson, R.A.; Duran, Y.; Carvalho, L.S.; Chu, C.J.; Naeem, A.; Blackford, S.J.I.; Georgiadis, A., Lakowski, J.; Hubank, M.; Smith, A.J.; Bainbridge, J.W.B.; Sowden, J.C.; Ali, R.R.

Photoreceptor precursors derived from three-dimensional embryonic stem cell cultures integrate and mature within adult degenerate retina. Nat Biotechnol.

2013, 31, 741-7. [PMID: 23873086] [PMCID: PMC3826328] [doi:

10.1038/nbt.2643]

69.- Klassen, H.J.; Ng, T.F.; Kurimoto, Y.; Kirov, I.; Shatos, M.; Coffey, P.; Young, M.J. Multipotent retinal progenitors express developmental markers, differentiate into retinal neurons, and preserve light-mediated behavior. Invest Ophthalmol Vis Sci. 2004, 45, 4167-4173. [PMID: 15505071] [doi:

10.1167/iovs.04-0511]

70.- Lamba, D.A.; Gust, J.; Reh, T.A. Transplantation of Human Embryonic Stem Cell-Derived Photoreceptors Restores Some Visual Function in CrxDeficient Mice. Cell Stem Cell. 2009, 4, 73-79. [doi:10.1016/j.stem.2008.10.015] 71- Tucker, B.A.; Park, I.H.; Qi, S.D.; Klassen, H.J.; Jiang, C.; Yao, J.; Redenti, S.; Daley, G.Q.; Young, M.J. Transplantation of adult mouse iPS cell-derived photoreceptor precursors restores retinal structure and function in degenerative mice. PLoS One. 2011, 6, e18992. [doi: 10.1371/journal.pone.0018992] Erratum in: PLoS One. 2015, 10, e0125947. [PMID: 21559507] [PMCID: PMC3084746]

72.- Homma, K.; Okamoto, S.; Mandai, M.; Gotoh, N.; Rajasimha, H.K.; Chang, Y.S.; Chen, S.; Li, W.; Cogliati, T.; Swaroop, A.; Takahashi, M. Developing rods transplanted into the degenerating retina of Crx-knockout mice exhibit neural activity similar to native photoreceptors. Stem Cells. 2013, 31, 1149-59. [PMID: 23495178] [PMCID: PMC4540234] [doi: 10.1002/stem.1372]

73.- Santos-Ferreira, T.; Völkner, M.; Borsch, O.; Haas, J.; Cimalla, P.; Vasudevan, P.; Carmeliet, P.; Corbeil, D.; Michalakis, S.; Koch, E.; Karl, M.O.; Ader, M. Stem Cell-Derived Photoreceptor Transplants Differentially Integrate Into Mouse Models of Cone-Rod Dystrophy. Invest Ophthalmol Vis Sci. 2016, 57, 3509-3520. [PMID: 27367586] [doi: 10.1167/iovs.16-19087]

74.- Singh, M.; Aslam, S.; Duncan, I.; Cramer, A.; Barnard, A.; MacLaren, R. Cell fusion following photoreceptor transplantation into the non-degenerate retina. Invest Ophthalmol Vis Sci. 2014, 55, 3989

75.- Ortin-Martinez, A.; Tsai, E.L.; Nickerson, P.E.; Bergeret, M.; Lu, Y.; Smiley, S.; Comanita, L.; Wallace, V.A. A Reinterpretation of Cell Transplantation: GFP 
Transfer From Donor to Host Photoreceptors. Stem Cells. 2017, 35, 932-939. [PMID: 27977075] [doi: 10.1002/stem.2552]

76- Siqueira, R.C.; Messias, A.; Messias, K.; Arcieri, R.S.; Ruiz, M.A.; Souza, N.F.; Martins, L.C.; Jorge, R. Quality of life in patients with retinitis pigmentosa submitted to intravitreal use of bone marrow-derived stem cells (Reticell -clinical trial). Stem Cell Res Ther. 2015, 6, 29. [PMID: 25890251] [PMCID:

PMC4393588] [doi: 10.1186/s13287-015-0020-6]

77.- Terrell, D.; Comander, J. Current Stem-Cell Approaches for the treatment of inherited retinal degenerations. Semin Ophthalmol. 2019, 34, 287-292. [doi: 10.1080/08820538.2019.1620808]

78.- Zheng, A.; Li, Y.; Tsang, S.H. Personalized therapeutic strategies for patients with retinitis pigmentosa. Expert Opin Biol Ther. 2015, 15, 391-402. [PMID: 25613576] [PMCID: PMC4377130] [doi:

10.1517/14712598.2015.1006192]

79.- Cai, B.; Sun, S.; Li, Z.; Zhang, X.; Ke, Y.; Yang, J.; Li, X. Application of CRISPR/Cas9 technologies combined with iPSCs in the study and treatment of retinal degenerative diseases. Hum Genet. 2018, 137, 679-688. [PMID: 30203114] [doi: 10.1007/s00439-018-1933-9]

80.- Burnight, E.R.; Wiley, L.A.; Mullins, R.F.; Stone, E.M.; Tucker, B.A. Gene therapy using stem cells. Cold Spring Harb Perspect Med. 2014, 5, a017434. [PMID: 25395375] [PMCID: PMC4382729] [doi: 10.1101/cshperspect.a017434] 81.- Chuang, K.; Fields, M.A.; Del Priore, L.V. Potential of Gene Editing and Induced Pluripotent Stem Cells (iPSCs) in Treatment of Retinal Diseases. Yale J Biol Med. 2017, 90, 635-642. [PMID: 29259527] [PMCID: PMC5733854] 82.- Liao, H.K.; Hatanaka, F.; Araoka, T.; Reddy, P.; Wu, M.Z.; Sui, Y.; Yamauchi, T.; Sakurai, M.; O'Keefe, D.D.; Núñez-Delicado, E.; Guillen, P.; Campistol, J.M.; Wu, C.J.; Lu, L.F.; Esteban, C.R.; Izpisua Belmonte, J.C. In Vivo Target Gene Activation via CRISPR/Cas9-Mediated Trans-epigenetic Modulation. Cell. 2017, 171, 1495-1507.e15. [PMID: 29224783] [PMCID: PMC5732045] [doi: 10.1016/j.cell.2017.10.025]

83.- Santiago, C.P.; Keuthan, C.J.; Boye, S.L.; Boye, S.E.; Imam, A.A.; Ash, J.D. A Drug-Tunable Gene Therapy for Broad-Spectrum Protection against Retinal Degeneration. Mol Ther. 2018; 26, 2407-2417. [doi:

10.1016/j.ymthe.2018.07.016]

84.- Cereso, N.; Pequignot, M.O.; Robert, L.; Becker, F.; De Luca, V.; Nabholz, N.; Rigau, V.; De Vos, J.; Hamel, C.P.; Kalatzis, V. Proof of concept for AAV2/5mediated gene therapy in iPSC-derived retinal pigment epithelium of a choroideremia patient. Mol Ther Methods Clin Dev. 2014, 1, 14011. [PMID: 26015956] [PMCID: PMC4362346] [doi: 10.1038/mtm.2014.11] 85.- Burnight, E.R.; Wiley, L.A.; Drack, A.V.; Braun, T.A.; Anfinson, K.R.; Kaalberg, E.E.; Halder, J.A.; Affatigato, L.M.; Mullins, R.F.; Stone, E.M.; Tucker, B.A. CEP290 gene transfer rescues Leber congenital amaurosis cellular phenotype. Gene Ther. 2014, 21, 662-672. [PMID: 24807808] [PMCID: PMC4188442] [. doi: 10.1038/gt.2014.39]

86.- Bassuk, A.G.; Zheng, A.; Li, Y.; Tsang, S.H.; Mahajan, V.B. Precision Medicine: Genetic Repair of Retinitis Pigmentosa in Patient-Derived Stem Cells. Sci Rep. 2016, 6, 19969. [PMID: 26814166] [PMCID: PMC4728485] [doi: 10.1038/srep19969]

87.- Garita-Hernandez, M.; Lampič, M.; Chaffiol, A.; Guibbal, L.; Routet, F.; Santos-Ferreira, T.; Gasparini, S.; Borsch, O.; Gagliardi, G.; Reichman, S.; 
Picaud, S.; Sahel, J.A.; Goureau, O.; Ader, M.; Dalkara, D.; Duebel, J. Restoration of visual function by transplantation of optogenetically engineered photoreceptors. Nat Commun. 2019, 10, 4524. [PMID: 31586094] [PMCID: PMC6778196] [doi: 10.1038/s41467-019-12330-2] 88- Drori, T.; Chapman, J. Diagnosis and classification of neuromyelitis optica (Devic's syndrome). Autoimmun Rev. 2014, 13, 531-533. [PMID: 24424197] [doi: 10.1016/j.autrev.2014.01.034]

89.- Mallick, J.; Devi, L.; Malik, P.K.; Mallick, J. Update on Normal Tension Glaucoma. J Ophthalmic Vis Res. 2016, 11, 204-208. [doi:10.4103/2008322X.183914]

90.- Kauper, K.; McGovern, C.; Sherman, S.; Heatherton, P.; Rapoza, R.; Stabila, P.; Dean, B.; Lee, A.; Borges, S.; Bouchard, B.; Tao, W. Two-year intraocular delivery of ciliary neurotrophic factor by encapsulated cell technology implants in patients with chronic retinal degenerative diseases. Invest Ophthalmol Vis Sci. 2012, 53, 7484-7491. [PMID: 23049090] [doi: 10.1167/iovs.12-9970] 91.- Birch, D.G.; Weleber, R.G.; Duncan, J.L.; Jaffe, G.J.; Tao, W. Ciliary Neurotrophic Factor Retinitis Pigmentosa Study Groups. Randomized trial of ciliary neurotrophic factor delivered by encapsulated cell intraocular implants for retinitis pigmentosa. Am J Ophthalmol. 2013, 156, 283-292.e1. [PMID: 23668681] [PMCID: PMC4111936] [doi: 10.1016/j.ajo.2013.03.021] 92.- Levison, S.W.; Ducceschi, M.H.; Young, G.M.; Wood, T.L. Acute exposure to CNTF in vivo induces multiple components of reactive gliosis. Exp Neurol. 1996, 141, 256-68. [PMID: 8812159] [doi: 10.1006/exnr.1996.0160] 93.- Amore, G.; Romagnoli, M.; Carbonelli, M.; Barboni, P.; Carelli, V.; La Morgia, C. Therapeutic Options in Hereditary Optic Neuropathies. Drugs. 2021, 81, 57-86. [PMID: 33159657] [doi: 10.1007/s40265-020-01428-3]

94.- Zhao, T.; Li, Y.; Tang, L.; Li, Y.; Fan, F.; Jiang, B. Protective effects of human umbilical cord blood stem cell intravitreal transplantation against optic nerve injury in rats. Graefes Arch Clin Exp Ophthalmol. 2011, 249, 1021-1028. [PMID: 21360302]. [doi: 10.1007/s00417-011-1635-7]

95.- Lopez Sanchez, M.I.; Crowston, J.G.; Mackey, D.A.; Trounce, I.A. Emerging Mitochondrial Therapeutic Targets in Optic Neuropathies. Pharmacol Ther. 2016, 165, 132-152. [PMID: 27288727] [doi:

10.1016/j.pharmthera.2016.06.004]

96.- Usategui-Martín, R.; Puertas-Neyra, K.; García-Gutiérrez, M.T.; Fuentes, M.; Pastor, J.C.; Fernandez-Bueno, I. Human Mesenchymal Stem Cell Secretome Exhibits a Neuroprotective Effect over In Vitro Retinal Photoreceptor Degeneration. Mol Ther Methods Clin Dev. 2020, 17, 1155-1166. [PMID: 32514411] [PMCID: PMC7267685] [doi: 10.1016/j.omtm.2020.05.003] 97.- Labrador-Velandia, S.; Alonso-Alonso, M.L.; Di Lauro, S.; García-Gutierrez, M.T.; Srivastava, G.K.; Pastor, J.C.; Fernandez-Bueno, I. Mesenchymal stem cells provide paracrine neuroprotective resources that delay degeneration of cocultured organotypic neuroretinal cultures. Exp Eye Res. 2019, 185, 107671. [PMID: 31108056] [doi: 10.1016/j.exer.2019.05.011]

98.- Weiss, J.N.; Levy, S. Stem Cell Ophthalmology Treatment Study (SCOTS): bone marrow derived stem cells in the treatment of Dominant Optic Atrophy. Stem Cell Investig. 2019, 5, 6:41. [PMID: 32039263] [PMCID: PMC6987313] [doi: 10.21037/sci.2019.11.01] 
99.- Nascimento-Dos-Santos, G.; Teixeira-Pinheiro, L.C.; da Silva-Júnior, A.J.; Carvalho, L.R.P.; Mesentier-Louro, L.A.; Hauswirth, W.W.; Mendez-Otero, R.; Santiago, M.F.; Petrs-Silva, H. Effects of a combinatorial treatment with gene and cell therapy on retinal ganglion cell survival and axonal outgrowth after optic nerve injury. Gene Ther. 2020, 27, 27-39. [PMID: 31243393] [doi: 10.1038/s41434-019-0089-0] 100.- Huang, H.; Kolibabka, M.; Eshwaran, R.; Chatterjee, A.; Schlotterer, A.; Willer, H.; Bieback, K.; Hammes, H.P.; Feng, Y. Intravitreal injection of mesenchymal stem cells evokes retinal vascular damage in rats. FASEB J. 2019, 33, 14668-14679. [PMID: 31690119] [doi: 10.1096/fj.201901500R] 101.- Labrador Velandia, S.; Di Lauro, S.; Alonso-Alonso, M.L.; Tabera Bartolome, S.; Srivastava, G.K.; Pastor, J.C.; Fernandez-Bueno, I. Biocompatibility of intravitreal injection of human mesenchymal stem cells in immunocompetent rabbits. Graefes Arch Clin Exp Ophthalmol. 2018, 256, 125134. [PMID: 29168045] [doi: 10.1007/s00417-017-3842-3] 102.- Park, S.S.; Bauer, G.; Abedi, M.; Pontow, S.; Panorgias, A.; Jonnal, R.; Zawadzki, R.J.; Werner, J.S.; Nolta, J. Intravitreal autologous bone marrow CD34+ cell therapy for ischemic and degenerative retinal disorders: preliminary phase 1 clinical trial findings. Invest Ophthalmol Vis Sci. 2014, 56, 81-89. [PMID: 25491299] [PMCID: PMC4288143] [doi: 10.1167/iovs.14-15415] 103.- Gu X; Yu X, Zhao C; Duan, P.; Zhao, T.; Liu, Y.; Li, S.; Yang, Z.; Li, Y.; Qian, C.; Yin, Z.; Wang, Y. Efficacy and Safety of Autologous Bone Marrow Mesenchymal Stem Cell Transplantation in Patients with Diabetic Retinopathy. Cell Physiol Biochem. 2018, 49, 40-52. [doi: 10.1159/000492838] 104.- China. Shanghai General Hospital, Shanghai Jiao Tong University School of Medicine. Role of the serum exosomal miRNA in diabetic retinopathy (DR). https://clinicaltrials.gov/ct2/show/NCT03264976. Accessed May 2, 2021. 105.- Castanheira P, Torquetti L, Nehemy MB, Goes AM. Retinal incorporation and differentiation of mesenchymal stem cells intravitreally injected in the injured retina of rats. Arq Bras Oftalmol. 2008, 71, 644-650. [PMID: 19039457] [doi: 10.1590/s0004-27492008000500007] 106.- van Zeeburg, E.J.; Maaijwee, K.J.; Missotten, T.O.; Heimann, H.; van Meurs, J.C. A free retinal pigment epithelium-choroid graft in patients with exudative age-related macular degeneration: results up to 7 years. $A m ~ J$ Ophthalmol. 2012, 153, 120-7.e2. [PMID: 21907969] [doi:

10.1016/j.ajo.2011.06.007] 107.- Ma, Z.; Han, L.; Wang, C.; Dou, H.; Hu, Y.; Feng, X.; Xu, Y.; Wang, Z.; Yin, Z.; Liu, Y. Autologous transplantation of retinal pigment epithelium-Bruch's membrane complex for hemorrhagic age-related macular degeneration. Invest Ophthalmol Vis Sci. 2009, 50, 2975-2981. [PMID: 19117919] [doi: 10.1167/iovs.08-2573] 108.- Jung, Y.H.; Phillips, M.J.; Lee, J.; Xie, R.; Ludwig, A.L.; Chen, G.; Zheng, Q.; Kim, T.J.; Zhang, H.; Barney, P.; Min, J.; Barlow, K.; Gong, S.; Gamm, D.M.; Ma, Z. 3D Microstructured Scaffolds to Support Photoreceptor Polarization and Maturation. Adv Mater. 2018, 30, e1803550. [PMID: 30109736] [doi: 10.1002/adma.201803550]

109.- Boyd, A.S.; Higashi, Y.; Wood, K.J. Transplanting stem cells: potential targets for immune attack. Modulating the immune response against embryonic stem cell transplantation. Adv Drug Deliv Rev. 2005, 57, 1944-1969. [PMID: 16289432] [doi: 10.1016/j.addr.2005.08.004] 
110.- Drukker, M.; Katz, G.; Urbach, A.; Schuldiner, M.; Markel, G.; ItskovitzEldor, J.; Reubinoff, B.; Mandelboim, O.; Benvenisty, N. Characterization of the expression of MHC proteins in human embryonic stem cells. Proc Natl Acad Sci U S A. 2002, 99, 9864-9. [PMID: 12114532] [PMCID: PMC125045] [doi: 10.1073/pnas.142298299]

111.- Araki, R.; Uda, M.; Hoki, Y.; Sunayama, M.; Nakamura, M.; Ando, S.; Sugiura, M.; Ideno, H.; Shimada, A.; Nifuji, A.; Abe, M. Negligible immunogenicity of terminally differentiated cells derived from induced pluripotent or embryonic stem cells. Nature. 2013, 494, 100-104. [doi: 10.1038/nature11807]

112.- Sugita, S.; Iwasaki, Y.; Makabe, K.; Kamao, H.; Mandai, M.; Shiina, T.; Ogasawara, K.; Hirami, Y.; Kurimoto, Y.; Takahashi, M. Successful Transplantation of Retinal Pigment Epithelial Cells from MHC Homozygote iPSCs in MHC-Matched Models. Stem Cell Reports. 2016, 7, 635-648. [PMID: 27641649] [PMCID: PMC5063629] [doi: 10.1016/j.stemcr.2016.08.010] 113.- Umekage, M.; Sato, Y.; Takasu, N. Overview: an iPS cell stock at CiRA. Inflamm Regen. 2019, 39, 17. [PMID: 31497180] [PMCID: PMC6717959] [doi: 10.1186/s41232-019-0106-0]

114.- Sugita, S.; Mandai, M.; Hirami, Y.; Takagi, S.; Maeda, T.; Fujihara, M.; Matsuzaki, M.; Yamamoto, M.; Iseki, K.; Hayashi, N.; Hono, A.; Fujino, S.; Koide, N.; Sakai, N.; Shibata, Y.; Terada, M.; Nishida, M.; Dohi, H.; Nomura, M.; Amano, N.; Sakaguchi, H.; Hara, C.; Maruyama. K.; Daimon, T.; Igeta, M.; Oda, T.; Shirono, U.; Tozaki, M.; Totani, K.; Sugiyama, S.; Nishida, K.; Kurimoto, Y.; Takahashi, M. HLA-Matched Allogeneic iPS Cells-Derived RPE Transplantation for Macular Degeneration. J Clin Med. 2020, 9, 2217. [PMID: 32668747] [PMCID: PMC7408794] [doi: 10.3390/jcm9072217]

115.- Hazra, S.; Stepps, V.; Bhatwadekar, A.D.; Caballero, S.; Boulton, M.E.; Higgins, P.J.; Nikonova, E.V.; Pepine, C.J.; Thut, C.; Finney, E.M.; Stone, D.J.; Bartelmez, S.H.; Grant, M.B. Enhancing the function of CD34(+) cells by targeting plasminogen activator inhibitor-1. PLoS One. 2013, 8, e79067. [PMID: 24223881] [PMCID: PMC3815099] [doi: 10.1371/journal.pone.0079067] 116.- Ueki, Y.; Wilken, M.S.; Cox, K.E.; Chipman, L.; Jorstad, N.; Sternhagen, K.; Simic, M.; Ullom, K.; Nakafuku, M.; Reh, T,A. Transgenic expression of the proneural transcription factor Ascl1 in Müller glia stimulates retinal regeneration in young mice. Proc Natl Acad Sci U S A. 2015, 112, 13717-13722. [PMID: 26483457] [PMCID: PMC4640735] [doi: 10.1073/pnas.1510595112]

117.- Mesentier-Louro, L.A.; Teixeira-Pinheiro, L.C.; Gubert, F.; Vasques, J.F.; Silva-Junior, A.J.; Chimeli-Ormonde, L.; Nascimento-Dos-Santo, G.; MendezOtero, R.; Santiago, M.F. Long-term neuronal survival, regeneration, and transient target reconnection after optic nerve crush and mesenchymal stem cell transplantation. Stem Cell Res Ther. 2019, 10, 121. [PMID: 30995945] [PMCID: PMC6472105] [doi: 10.1186/s13287-019-1226-9]

118.- Barber A, Farmer K, Martin KR, Smith PD. Retinal regeneration mechanisms linked to multiple cancer molecules: A therapeutic conundrum. Prog Retin Eye Res. 2017, 56, 19-31. [PMID: 27586058] [doi: 10.1016/j.preteyeres.2016.08.003]

119.- Mead, B.; Tomarev, S. Bone Marrow-Derived Mesenchymal Stem CellsDerived Exosomes Promote Survival of Retinal Ganglion Cells Through miRNADependent Mechanisms. Stem Cells Transl Med. 2017, 6, 1273-1285. [PMID: 28198592] [PMCID: PMC5442835] [doi: 10.1002/sctm.16-0428] 
120.- Gramlich, O.W.; Brown, A.J.; Godwin, C.R.; Chimenti, M.S.; Boland, L.K.; Ankrum, J.A.; Kardon, R.H. Systemic Mesenchymal Stem Cell Treatment Mitigates Structural and Functional Retinal Ganglion Cell Degeneration in a Mouse Model of Multiple Sclerosis. Trans/ Vis Sci Technol. 2020, 9, 16. [PMID: 32855863] [PMCID: PMC7422913] [doi: 10.1167/tvst.9.8.16] 
Table 1. Optic nerve regeneration: failed cell therapy clinical trials for optic nerve disorders.

\section{Reference}

NTC 01364246

Phase I/II Study

NTC 01834079

Phase I/II Study

NCT 02249676

Phase II Study

NTC 03605238

Phase I Study

NTC 02976441

Phase I Study

NTC 02144103

Phase I/II Study

NTC 01339455

Phase I/II Study
Disease

Multiple sclerosis

and Neuromyelitis

optica

Optic nerve atrophy

Neuromyelitis optica

Neuromyelitis optica

High grade gliomas

Retinal Degeneration \&

Primary Open-Angle Glaucoma

Neuromyelitis optica
Bone Marrow Derived Autologous Cells

Autologous

Cell type

Umbilical Cord cells

mesenchymal stem cells

TanCART19/20

Autologous Stem Cell Collection

Autologous adiposederived regenerative cells (ADRC)

Autologous

hematopoietic stem cell transplant
Mesenchymal Stem
Administration route Study start date:

Status

hUC-MSCs
transplantation

January 2010

Unknown

Intra thecal injection

of MNCs cells

September $2014 \quad$ Unknown

MSC a day-case $2 \cdot 0 \times 106$ cells $/ \mathrm{kg}$ i.v.

January 2013

Unknown

Anti-CD19/20 CAR T cells infusion

August 2018

Withdrawn

Stem cell infusion

January 2017

Withdrawn

Subtenon
administration of
autologous ADRC

May 2014

Unknown autologous ADRC

Terminated

Intravenous infusion

April 2011 (recruitment failure) 
Table.2. Optic nerve regeneration: cell therapy clinical trials for optic nerve disorders.

\begin{tabular}{|c|c|c|c|c|c|c|}
\hline Reference & Disease & Cell type & Administration route & Sponsor & Study start date: & Status \\
\hline $\begin{array}{l}\text { NTC } 02638714 \\
\text { Phase I/II Study }\end{array}$ & Optic nerve atrophy & $\begin{array}{l}\text { Autologous Bone- } \\
\text { Marrow } \\
\text { CD 34+, 133+, and } \\
271+\text { Stem Cells }\end{array}$ & $\begin{array}{l}\text { Transplantation of } \\
\text { autologous purified stem } \\
\text { cells (no site declared) }\end{array}$ & $\begin{array}{l}\text { Stem Cells } \\
\text { Arabia }\end{array}$ & April 2013 & Recruiting \\
\hline $\begin{array}{l}\text { NTC } 03173638 \\
\text { Phase II Study }\end{array}$ & $\begin{array}{c}\text { Acute Ischemic optic } \\
\text { neuropathy Non Arteritic }\end{array}$ & $\begin{array}{c}\text { Allogenic } \\
\text { mesenchymal stem } \\
\text { (MSV) cells from } \\
\text { bone marrow }\end{array}$ & $\begin{array}{l}\text { Intravitreal injection of of } \\
\text { MSV cells }\end{array}$ & IOBA, Spain & March 2018 & Recruiting \\
\hline $\begin{array}{l}\text { NCT } 022836771 \\
\text { Phase I Study }\end{array}$ & Neuromyelitis optica & $\begin{array}{c}\text { Tolerogenic } \\
\text { Dendritic cells } \\
\text { loaded with myelin } \\
\text { peptides }\end{array}$ & intravenous administration & $\begin{array}{l}\text { Hospital } \\
\text { Clinic of } \\
\text { Barcelona, } \\
\text { Spain }\end{array}$ & $\begin{array}{l}\text { September } \\
2015\end{array}$ & Completed \\
\hline $\begin{array}{l}\text { NTC } 01920867 \\
\text { Phase (n/a) }\end{array}$ & $\begin{array}{l}\text { Various ocular diseases including } \\
\text { optic neuritis }\end{array}$ & $\begin{array}{l}\text { Bone Marrow } \\
\text { Derived Stem Cells } \\
\text { (BMSC). Study I }\end{array}$ & $\begin{array}{l}\text { Injections of BMSC } \\
\text { retrobulbar (RB), subtenon } \\
\text { (ST) and intravenous (IV) }\end{array}$ & $\begin{array}{l}\text { MD Stem } \\
\text { Cells, USA }\end{array}$ & August 2012 & $\begin{array}{l}\text { Enrolling by } \\
\text { invitation }\end{array}$ \\
\hline $\begin{array}{l}\text { NTC } 03011541 \\
\text { Phase }(n / a)\end{array}$ & $\begin{array}{c}\text { Various ocular diseases including } \\
\text { Optic Neuropathy } \\
\text { Nonarteritic Ischemic Optic } \\
\text { Neuropathy } \\
\text { Optic Atrophy, Optic Nerve } \\
\text { Disease, } \\
\text { Glaucoma, } \\
\text { Leber Hereditary Optic } \\
\text { Neuropathy }\end{array}$ & $\begin{array}{c}\text { Bone Marrow } \\
\text { Derived Stem Cells } \\
\text { (BMSC). Study II }\end{array}$ & $\begin{array}{l}\text { Injections of BMSC } \\
\text { retrobulbar, subtenon and } \\
\text { intravenous }\end{array}$ & $\begin{array}{l}\text { MD Stem } \\
\text { Cells, USA }\end{array}$ & January 2016 & Recruiting \\
\hline $\begin{array}{l}\text { NTC } 00787722 \\
\text { Phase I/II Study }\end{array}$ & Devic Neuromyelitis & $\begin{array}{l}\text { High Dose } \\
\text { immunosuppressive } \\
\text { therapy with } \\
\text { hematopoietic stem } \\
\text { cells transplantation }\end{array}$ & Intravenous infusion & $\begin{array}{l}\text { Northwestern } \\
\text { University, } \\
\text { USA }\end{array}$ & October 2009 & Completed \\
\hline $\begin{array}{l}\text { NTC } 00716066 \\
\text { Phase II Study }\end{array}$ & $\begin{array}{l}\text { Neurologic autoimmune diseases, } \\
\text { including neuromyelitis optica }\end{array}$ & $\begin{array}{c}\text { High Dose } \\
\text { immunosuppressive } \\
\text { therapy with } \\
\text { autologous } \\
\text { hematopoietic stem } \\
\text { cell transplantation }\end{array}$ & Intravenous infusion & $\begin{array}{c}\text { Fred } \\
\text { Hutchinson } \\
\text { Cancer } \\
\text { Research } \\
\text { Center } \\
\text { National } \\
\text { Cancer } \\
\text { Institute, USA }\end{array}$ & June 2008 & Recruiting \\
\hline $\begin{array}{l}\text { NTC } 04577300 \\
\text { Phase II Study }\end{array}$ & Glaucoma & $\begin{array}{l}\text { Dual NT-501 CNTF } \\
\text { encapsulated cell } \\
\text { therapy }\end{array}$ & Intravitreal NT-501 implants & $\begin{array}{l}\text { Stanford } \\
\text { University, } \\
\text { USA }\end{array}$ & October 2020 & $\begin{array}{l}\text { Not yet } \\
\text { recruiting }\end{array}$ \\
\hline $\begin{array}{l}\text { NTC } 02862938 \\
\text { Phase II Study }\end{array}$ & Glaucoma & $\begin{array}{c}\text { NT-501 CNTF } \\
\text { encapsulated cell } \\
\text { therapy }\end{array}$ & Intravitreal NT-501 implants & $\begin{array}{l}\text { Stanford } \\
\text { University, } \\
\text { USA }\end{array}$ & August 2016 & $\begin{array}{l}\text { Active, not } \\
\text { recruiting }\end{array}$ \\
\hline $\begin{array}{l}\text { NTC } 02330978 \\
\text { Phase I Study }\end{array}$ & Glaucoma & $\begin{array}{c}\text { Autologous Bone } \\
\text { Marrow-derived } \\
\text { Mesenchymal Stem } \\
\text { Cell Transplantation } \\
\text { Intravitreal }\end{array}$ & Intravitreal & $\begin{array}{l}\text { University of } \\
\text { Sao Paulo, } \\
\text { Brazil }\end{array}$ & July 2019 & Completed \\
\hline
\end{tabular}

(n/a): not applicable; (CNTF): soluble ciliary neurotrophic factor 